\title{
Use of Zebrafish Models to Boost Research in Rare Genetic Diseases
}

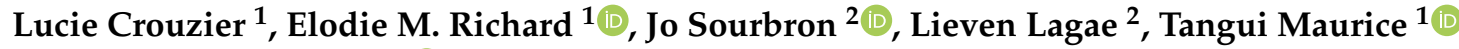 \\ and Benjamin Delprat ${ }^{1, * \mathbb{C}}$
}

1 MMDN, University of Montpellier, EPHE, INSERM, 34095 Montpellier, France; lucie.crouzier@umontpellier.fr (L.C.); elodie.richard@umontpellier.fr (E.M.R.); tangui.maurice@umontpellier.fr (T.M.)

2 Department of Development and Regeneration, Section Pediatric Neurology, University Hospital KU Leuven, 3000 Leuven, Belgium; j.sourbron@gmail.com (J.S.); lieven.lagae@uzleuven.be (L.L.)

* Correspondence: benjamin.delprat@inserm.fr; Tel.: +33-(0)4-6714-3623

Citation: Crouzier, L.; Richard, E.M.; Sourbron, J.; Lagae, L.; Maurice, T.; Delprat, B. Use of Zebrafish Models to Boost Research in Rare Genetic Diseases. Int. J. Mol. Sci. 2021, 22, 13356. https://doi.org/10.3390/ ijms222413356

Academic Editors: Rene Hurlemann, Claude Meunier, Shlomo Wagner and Nicolas Marie

Received: 7 October 2021

Accepted: 10 December 2021

Published: 12 December 2021

Publisher's Note: MDPI stays neutral with regard to jurisdictional claims in published maps and institutional affiliations.

Copyright: (C) 2021 by the authors Licensee MDPI, Basel, Switzerland. This article is an open access article distributed under the terms and conditions of the Creative Commons Attribution (CC BY) license (https:// creativecommons.org/licenses/by/ $4.0 /)$
Abstract: Rare genetic diseases are a group of pathologies with often unmet clinical needs. Even if rare by a single genetic disease (from $1 / 2000$ to 1 /more than $1,000,000$ ), the total number of patients concerned account for approximatively 400 million peoples worldwide. Finding treatments remains challenging due to the complexity of these diseases, the small number of patients and the challenge in conducting clinical trials. Therefore, innovative preclinical research strategies are required. The zebrafish has emerged as a powerful animal model for investigating rare diseases. Zebrafish combines conserved vertebrate characteristics with high rate of breeding, limited housing requirements and low costs. More than $84 \%$ of human genes responsible for diseases present an orthologue, suggesting that the majority of genetic diseases could be modelized in zebrafish. In this review, we emphasize the unique advantages of zebrafish models over other in vivo models, particularly underlining the high throughput phenotypic capacity for therapeutic screening. We briefly introduce how the generation of zebrafish transgenic lines by gene-modulating technologies can be used to model rare genetic diseases. Then, we describe how zebrafish could be phenotyped using state-of-the-art technologies. Two prototypic examples of rare diseases illustrate how zebrafish models could play a critical role in deciphering the underlying mechanisms of rare genetic diseases and their use to identify innovative therapeutic solutions.

Keywords: animal model; rare diseases; zebrafish; phenotyping; Wolfram syndrome; Dravet syndrome

\section{Introduction}

Rare diseases are commonly defined by their low prevalence in the general population. While there is no worldwide consensus on the definition and, more particularly, a prevalence cut-off number, the European Union stated that any life-threatening or chronically debilitating disease affecting fewer than 1 out of 2000 individuals qualifies as a rare disease. Collectively, these conditions affect around 30 million people in the European Union alone, thus posing a tremendous societal burden. Numerous rare diseases are severe, chronic, mostly genetic in origin and progressive and can be symptomatic as soon as birth or childhood (e.g., infantile spinal muscular atrophy, neurofibromatosis, osteogenesis imperfecta, chondrodysplasias, or Rett syndrome). Others appear only in adulthood (e.g., Huntington's, Crohn's, or Charcot-Marie-Tooth's diseases, amyotrophic lateral sclerosis, Kaposi's sarcoma and thyroid cancer). There are approximately 8000 rare diseases worldwide and those affected have little hope of treatment due to the lack of knowledge about the pathophysiological mechanism of the disease or the relative lack of private sector investment for therapies that finally concern only few patients and, likely, do not provide a sufficient return on investment. Therefore, it is essential to step up research efforts on rare diseases, at the epidemiological, clinical, genetic and pathophysiological levels, in order to elucidate 
their biological mechanisms and discover effective therapies. Using powerful technological tools and robust animal models, the pathogenic mechanisms of many rare diseases should be elucidated. It would be important to promote therapeutic research using technological innovations, such as monoclonal antibodies and gene therapy, or even by the discovery of active chemical compounds.

The zebrafish (Danio rerio) is a small tropical freshwater fish species native from Southern Asia and they were first described in 1822 by the Scottish naturalist Francis BuchananHamilton [1]. In recent decades, the zebrafish has become a popular laboratory model, as it bears many significant advantages over other models. This small aquatic vertebrate is easy to maintain in an animal facility and at low costs. Female fish lay a large numbers of eggs per week and the embryos develop quickly and externally through six stages, i.e., embryonic pre-hatching (0-72 h post-fertilization, hpf), post-hatching (72-120 hpf), larval (5-29 days post-fertilization, dpf), juvenile fish (30-89 dpf), adult fish ( $90 \mathrm{dpf}-2$ years) and aged fish (from 2 years) [2,3]. In addition, the fully sequenced zebrafish genome [4] reveals that $70 \%$ of human protein-coding genes are linked to genes found in zebrafish and $84 \%$ of genes known to be associated with human disease have a homologous gene in zebrafish [4]. This renders the model relevant to study genetic disorders linked to human diseases [5-7] and particularly neurodegenerative and neurological disorders [8-11]. To accomplish this, an increasing range of reverse genetic techniques are available to generate new zebrafish models and identify novel genes of interest with potential relevance to human diseases.

Interestingly, several zebrafish organ systems are remarkably similar to those in humans. In addition to neuroanatomical similarities, the zebrafish nervous system also expresses many signaling molecules with a high level of similarity to mammals in terms of signaling pathways, conferring a good descriptive validity in pathophysiological analyses [12-14].

Finally, the robustness of their easily quantifiable phenotypes, the ease of treatment with water and a high sensitivity to drugs due to their blood-brain barrier tight junction $[15,16]$, make zebrafish a powerful animal model to identify high-throughput neuroactive compounds. This illustrates the value of this organism as an indispensable model of human neurodegenerative diseases.

In this review, we detail the usefulness of zebrafish lines for the phenotypic analyses of rare genetic diseases and, particularly, exemplify two zebrafish models prototypic for these pathologies, namely, the Wolfram and Dravet syndromes, to help illustrating the relevance for using zebrafish to address pathophysiological mechanisms and drug screening. We also review the tools currently available and their utility in analyzing the zebrafish phenotypes, in particular in the context of defective pathways leading to locomotion, vision, hearing impairments and epileptic phenotypes.

\section{Zebrafish as a Genetic Disease Model}

An animal model gives the prime opportunity to study how genetic and environmental factors can lead to several symptoms related to the disorder.

Zebrafish were initially used in laboratory because of their ability to produce large batches of transparent embryos and to study their embryonic development [17-19]. The model allowed researchers to obtain a better understanding of a wide range of cellular mechanisms integrating living organisms such as hepatocarcinogenesis [20], the effects of toxins and alcohol on embryogenesis [21] and tissues and organs regeneration [22-24]. Now, zebrafish is commonly used in a variety of biological disciplines ranging from basic developmental biology to applied toxicology. In 2017, more than 1200 laboratories worldwide used this species, in connection with very diverse questions such as the formation and/or regeneration of organs, the intimate functioning of the nervous system, the biological effects of pollutants, or the response to infections, among other examples. Furthermore, the zebrafish is used to model a variety of human diseases, from hereditary muscle diseases [25], neurological disorders [26], cancer [27] and cardiovascular diseases [28] to hematopoietic or infectious diseases [29]. Despite notable differences from 
human pathophysiology, the zebrafish is a valuable vertebrate model to study vision [30] and hearing disorders [31].

\subsection{Genetic Approaches}

In recent years, thanks to innovative technical means [32], it has become possible and relatively easy to mimic human pathologies rapidly and on a large scale in zebrafish by modifying its genome, opening up a very wide field of applications and the search for (novel) therapies.

\subsubsection{Forward Genetics}

One strategy, termed forward genetics, is based on the identification of an unknown gene by studying the mutant phenotype of an animal model. The most common technique used to induce mutagenesis consists in exposing germ cells to N-ethyl-N-nitrosourea (ENU), an alkylating agent, that alters, punctually and randomly, the nucleotide sequence of a very large number of genes. Depending on the position within an open reading frame (ORF) or at splicing sites, this can result in a nonsense mutation leading to protein truncation or a missense mutation changing the meaning of the affected codon. ENU treatment can induce loss-of-function and gene inactivation that are transmitted by successive crossings. Then, the thousands of mutants thus generated, each carrying different mutations, are screened to detect potential morphological and functional anomalies [33]. To note, the $d i d y^{5552}$ line, a zebrafish model for Dravet syndrome, was discovered through ENU-induced zebrafish mutant bank screening [34].

\subsubsection{Reverse Genetics}

Powerful reverse genetic methods, such as transient injection of antisense morpholino oligonucleotides (MOs) in embryos, allowed researchers to selectively inhibit gene translation or appropriate splicing and resulted in the transient slaughter of specific genetic products $[35,36]$. While representing an easy and fast method to generate mutant larvae, the so-called morphants, MOs have disadvantages, including toxicity, incomplete knockdown and occasional off-target nonspecific deleterious effects [37]. Although being relatively stable, MOs become diluted in the animal, implying that their efficacy diminishes at later stages. Therefore, such method is limited to processes occurring during the first 5 days of the fish development, thus excluding certain studies whose phenotypes appear during the juvenile or adult stage.

RNA interference (RNAi) is a single or double RNA whose interference with a specific mRNA leads to its degradation and to a decrease in the expression of the relevant protein. Insofar as RNA plays a crucial role in gene expression, RNAi blocks it by silencing a particular gene. It is seen as a product of evolution allowing organisms to defend themselves against the introduction of foreign genomes, particularly from viral origin, or even allowing gene expression to be modulated. RNAi by injection has somewhat limited applications, as this approach is restricted to studies of gene function during embryonic development; further, maternally loaded proteins may mask embryonic phenotypes. As of today, this method has not been extensively developed in zebrafish [38].

In order to create gain of function mutant, mRNA injection of synthetic capped mRNA encoding the protein of interest in early embryonic stages (one- or two-cell embryos) is a widely used method. The injected mRNA is distributed more or less evenly with each new cell born from the embryo. The derived mRNA overexpression is a rapid tool for the functional analysis of genes by global expression of gain and loss of function variants of a gene of interest $[39,40]$. However, this method is limited to the early stages of the embryogenesis process, because, as observed with MOs, the injected mRNA is not longlastingly stable.

Other methods of DNA editing, such as the transcription activator-like effector nucleases (TALEN), zinc-finger nucleases (ZFN) or the CRISPR/Cas9 strategy [41-44], are used to create targeted mutations and to develop stable models of human pathologies [45-49]. 
The CRISPR/Cas9 technology allows a more precise genome editing, with a site specific insertion of a conditional cassette, to be performed, drastically expending the genetic possibilities [50].

\subsection{Zebrafish as a Model of Eye Diseases}

Vision is among the different functions that can be easily tested using zebrafish models. In fact, the visual system of zebrafish is similar to the human one, with an initial development of the eye structure which, overall, resembles those of other vertebrates [51] but presents some notable structural differences. First, zebrafish eyes are in lateral position with a little overlapped binocular vision, contrary to humans, whose eyes are frontal with highly overlapped binocular vision. In addition, the fovea, the area of the retina where the vision of details is the most precise, is absent in zebrafish. All their optic nerve projections cross at the midline, forming a complete optic chiasm, whereas, in humans, half of the optic fibers project to the ipsilateral side of the tectum [52]. Next, the zebrafish lens is spheroid, extending through the iris and conferring a wide field of vision, compared to humans' lens, which is ellipsoid. Finally, zebrafish have a tetrachromatic vision, while humans have a trichromatic vision, lacking sensitivity to ultraviolet light [53].

As zebrafish use vision to protect themselves from predators and seek food, their visual system develops rapidly. Similar to the human eye, the retina is composed of different cell types and organized in nuclear layers separated by plexiform layers. Three nuclear layers contain the cell somas, i.e., the outer nuclear layer (ONL), the inner nuclear layer (INL), the ganglion cell layer (GCL) and two plexiform layers, forming an area where axons and dendrites make synapses - the inner plexiform layer and the outer plexiform layer. Photoreceptor (rods and cones) and horizontal cell bodies are located in the ONL, while bipolar, amacrine and Müller glial cells reside in the INL. The GCL is composed of the cell bodies of ganglion cells and their axons constitute the retinal nerve layer to carry the visual information from the eye to the brain [54].

Photoreceptor cells are grouped into rods and cones, arranged in a mosaic pattern in the ONL and specialized for phototransduction. Zebrafish photoreceptor cells have two major subtypes, namely, rods, which are sensitive to light and permit for dim light vision, and cones, subdivided into four classes that include blue-sensitive cones (407-417 nm), green-sensitive cones (473-480 $\mathrm{nm}$ ), red-sensitive cones (556-564 $\mathrm{nm}$ ) and UV-sensitive cones $(360-361 \mathrm{~nm})[55,56]$. The latter are involved in vision during bright light as well as color vision. Interestingly, the UV-sensitive cones develop first and are visible in the retina at 4 days post fertilization (dpf). They are followed by short, middle and long sensitive cones. Rod photoreceptors are present at $5 \mathrm{dpf}$ but their contribution is only measured at stages older than 15-21 dpf. The visual system of the zebrafish becomes functional about $3.5 \mathrm{dpf}$. However, recent studies suggested that rod photoreceptors may be functional at $5 \mathrm{dpf}$ by using a modified visual motor response protocol [57,58]. At this stage, all types of retinal cells are differentiated and the retinal circuits and their projection towards the brain have matured enough to support the first visually triggered motor behaviors, such as visual startle and optokinetic responses $[54,59,60]$.

Despite the differences described above, the zebrafish visual system better reflects the human system than any other animal model. Indeed, mice have a vision dominated by rods, whereas, as mentioned previously, zebrafish have a predominantly conical human-like vision. Therefore, the study of human disorders related to cone degeneration are more relevant in zebrafish models. In addition, the visual system develops faster in zebrafish than in mice, this being mature at $5 \mathrm{dpf}$ in zebrafish vs. 15 days of life in mice. Taken together, these facts support the use of zebrafish as an excellent model for understanding human ocular diseases $[45,61,62]$.

\subsection{Measurement of Visual Behavior in Zebrafish}

To assess visual functions and their potential alteration in Zebrafish, various tests have been developed. In this review, we focus on the three most popular ones in laboratory practice. 
The optomotor response (OMR) is an innate orienting behavior evoked by whole-field visual motion and is common to fish during locomotion, such as when swimming. Thus, the OMR test has been developed as a tool measuring the vision of larvae or adult zebrafish and mediated by the red/green cones pathway $[63,64]$.

Movable black-and-white bands revolve around or below the fish that tends to swim in the same direction as the bands. The OMR behavior is a result of the larvae attempting to counter water currents and to remain in place. A control fish with no visual problem swims in the direction of the bands, while a fish with visual impairment swims randomly. The striped pattern can be changed by modulating the contrast of the bands or the wavelength of the OMR. A large number of fish can be tested at the same time, making the OMR test useful for screening at high speed. The assay can be performed as early as $6 \mathrm{dpf}$, the time of onset of this adaptive behavior [53].

This visual test has been used in genetic screens to identify mutations disrupting the development and function of the visual system [63]. It has been efficiently used to screen molecules as different compounds can be tested with various fish concomitantly or with isolated fish [65].

The optokinetic response $(O K R)$ is the eye movement reflex in response to a moving stimulus to help stabilize the image on the retina maintaining visual acuity [66]. This ability develops at $3 \mathrm{dpf}$ [60] and matures significantly by the 5th dpf. This natural response is important for spatial orientation, hunting their prey and escaping from predators.

During the OKR assay, zebrafish larvae are usually immobilized in a methylcellulose solution with eyes keeping the ability to move. A black-and-white striped pattern moves around the fish and the speed of rotation of the bands, their frequency and the contrast can be modified [53]. The eyes of the larvae are pigmented; therefore, their movements can be easily tracked under a binocular magnifier or a camera connected to a computer equipped with tracking software [67]. Eye movements, called saccades, consist of a smooth pursuit (slow phase) in the direction of the rotation of the stimulus and a fast resetting (fast phase) in the opposite direction after the image left the visual field. The number of saccades reflects the quality of visual acuity, with a small number of saccades indicating a visual impairment. The speed, amplitude and duration of the saccades can also be quantified and used as indicators of the visual deficit. Therefore, the optokinetic response can be successfully used to screen visual performance following genetic manipulations and/or drug treatments $[65,68]$.

The visual motor response (VMR) is a sensorimotor behavior resulting in a rapid and protective response to sudden stimuli, observed within a couple of seconds following a visual stimulus. This natural response, based on the natural tendency to flee from predators, develops at $72 \mathrm{hpf}$ and is based, more specifically, on the larvae's ability to detect sudden changes in light [69]. This test is complementary to the OKR and allows researchers to discriminate the ability of the fish to detect movement (=OKR) from changes in light intensity (=VMR).

The locomotor response of each larva, following a controlled change in white light, is quantified by an automated tracking system. The movement is quantified as a number of video pixels changing beyond a predefined threshold in successive images. This frameby-frame movement can be averaged over a specific period of time. In control fish, the locomotor activity increases drastically following a light-dark transition and returns to the baseline when the dark-light transition takes place. Thus, the difference in reaction caused by the change in brightness can be measured and compared as a function of the different genotypes tested [69].

The VMR test can be used as a powerful tool for a high-throughput in vivo screening platform for pharmacologically active molecules [68,70]. Indeed, a large number of fish can be tested simultaneously. Automated quantification and execution ensure reproducible results, which are key in drug screening assays. 


\subsection{Zebrafish as a Model of Deafness}

Numerous studies have highlighted that the zebrafish is also an excellent model for hearing and balance disorders [71-74], hair cell death and regeneration, ototoxicity and drug screening [75-79].

One specific advantage of using zebrafish is the conservation, in vertebrates, of the anatomy and physiology of the inner ear structures [80,81]. Most particularly, the anatomical characteristics of the vestibular labyrinth are highly conserved in terms of structure and function. The vestibular system, composed of two otolithic organs (saccule and utricle) and three semicircular canals (horizontal, vertical anterior and posterior canal), maintaining the body balance. The detection of linear horizontal acceleration occurs in the utricle and the semicircular canals detect angular acceleration in different planes. The saccule is used, in humans, for the detection of vertical acceleration. However, in zebrafish, the saccule is thought to be primarily responsible for sound detection, with frequencies between $200 \mathrm{~Hz}$ and $4000 \mathrm{~Hz}$.

The inner ear of mammals comprises also the cochlea, a bony labyrinth filled with fluid, which transduces sound stimuli. It contains the organ of Corti, consisting of about 20,000 sensory receptors, called hair cells because of their protruding stereocilia bundles. The cochlea and the vestibular system are connected to the brain by the eighth cranial nerve (vestibulocochlear). One branch of this nerve, the auditory nerve, transmits sound signals to the brain and another transmits signals related to balance.

Fish do not have a dedicated auditory organ such as the mammalian cochlea, but their inner ear is made of three chambers, i.e., the saccule and the lagena, which are necessary for auditory perception, and the utricle, which is essential for postural equilibrium [82-84]. These compartments, filled with liquid, are attached, at their posterior end, to four small bones, the Weberian ossicles, which are interconnected by ligaments and form a connection to the swim bladder. The Weberian ossicles function as an accessory hearing structure transmitting sound vibrations from the swim bladder to the sensory organs of the inner ear [85].

The semicircular canals are also present with the same functions as in humans. They are lined with connected hair cells that bathe in a fluid with high potassium concentration called endolymph. In the presence of vibrations due to sound, the cells vibrate and send a nervous message to the brain [86]. The morphological, electrophysiological, biochemical and molecular characteristics of hair cells are largely preserved from fish to human. A number of genes necessary for hair cell development and function in zebrafish have been shown to be associated with hearing loss in mice and humans, revealing their conserved function [83].

In some species, the swim bladder is connected to the inner ear either directly through small canals or via a chain of bones and transmits high-frequency sounds. Each of these compartments contains an otolith, a crystalline structure of calcium carbonate $\left(\mathrm{CaCO}_{3}\right)$ involved in the body balance. Each fish has three otoliths, namely, the lapillus, sagitta and asteriscus. During movement or vibration, otoliths exert pressure on the ciliary bundles of macular hair cells, which become deflected and send signals to the brain. These signals are used for hearing or balancing, in fish.

In addition to the ear, zebrafish possess another mechanosensory system that employs sensory hair cells, the lateral line organ. It encodes hydrodynamic information required for fundamental behaviors, including rheotaxis [87-89], schooling behavior [90], prey detection [91-93] and predator avoidance [94].

The lateral line contains hair cells and supporting cells in sensory patches, on the surface of the epidermis or inside epidermal canals, called neuromasts. Arranged in precise lines over the body surface, each neuromast is innervated by two bipolar neurons located in a cranial ganglion and establishes its central projection in the rhombencephalon, whence sensory information is transmitted to the brain [95]. The stereocilia bundles of the sensory cells are embedded in a gelatinous cupula which projects into the water and is deflected by the stream of water [96]. Due to the similarities between human hair cells 
and zebrafish neuromasts, great attention was given to their development [97,98], as well as their regenerative capacity, which distinguishes them from the hair cells of the human ear [99].

\subsection{Measurement of Hearing Behavior in Zebrafish}

Similar to the hair cells in the inner ear of mammals, hair cells in the zebrafish lateral line are killed by exposure to chemicals, including aminoglycosides and cisplatin [99-101]. The ease of visualization-thus of quantification as well as the cellular and molecular properties shared with the hair cells of the inner ear-renders this system a good model to study the genetic and pharmacological modulation of the sensitivity of hair cells to potentially ototoxic agents [102]. In recent years, induced ototoxicity of the lateral line of zebrafish testing has become a powerful biological model system to develop new drugs to halt or prevent hearing loss. Among other studies, Domarecka et al. [103] and Vlasits et al. [104] used the zebrafish lateral line to screen a library of repurposing Food and Drug Administration (FDA)-approved drugs (Enzo 640) and identified two therapeutic drugs, paroxetine and benzamil, which protected against cisplatin-induced hair cell death.

At $5 \mathrm{dpf}$, zebrafish have a functional hearing system comparable to that of mammals [105] and can initiate an escape response to a sudden acoustic stimuli [106,107]. The characteristics of the zebrafish auditory system facilitates the study of the effects of noise on the inner ear and behavioral response pathways. The acoustic startle response (ASR) is a muscular activity, produced by reflex in response to a more or less loud and sudden sound, that is easy to measure and quantify [108]. As for the VMR test, following a sound stimulus, the ASR measures the locomotor response of each larva in a 96-well plate using an automated tracking system. In a physiological condition, the locomotor activity of control larvae increases strongly following the sound stimulus and returns to a baseline in the absence of sound. In a pathological condition, the reaction of mutant larvae or larvae previously treated with ototoxic agents to the sound stimulus is altered. The difference in reaction can be objectively measured and compared as a function of different conditions tested [109].

\subsection{Zebrafish as a Model of Epilepsy}

Epilepsy is a relatively prevalent neurological disease affecting nearly 70 million people worldwide and is characterized by recurrent seizures [110]. Even though patients with epilepsy (PWEs) are a heterogeneous group, they share the excessive neuronal excitation during a seizure; this can be caused by alterations in (i) inhibitory and/or excitatory neurotransmission or (ii) gene expression encoding proteins modulating neuronal activity, e.g., ion channels such as the sodium voltage-gated channel alpha subunit 1 (SCN1A). The International League Against Epilepsy (ILAE) has made the following etiological classification into six subgroups: (1) structural cause, (2) genetic mutation, (3) metabolic defect, (4) abnormal immune reaction, (5) infection and (6) unknown [111]. In nearly 30\% of the PWEs, the cause is unknown. Structural anomalies (e.g., traumatic brain injury, tumor, or stroke) and infection (e.g., encephalitis) are among the most common causes [112].

Even though zebrafish models offer prodigious possibilities to mimic these causes, there is still an unmet need to investigate epileptogenesis, mechanistic pathways and novel anti-seizure medication (ASM) in these zebrafish models [112].

In contrast, genetic causes of epilepsy have been extensively studied in zebrafish, partially due to the fact that $80 \%$ of the known epilepsy-related genes are found in the zebrafish genome [113-117]. Interestingly, developmental and epileptic encephalopathies (DEE), due to genetic defects, are more common in younger PWEs [118] and, in some PWEs, one single gene can be causative for the epileptic phenotype [119]. Thanks to the powerful, ever-expanding and effective techniques for zebrafish genome manipulation, we are able to generate zebrafish epilepsy models, recapitulating the main characteristics of the human disease [112,120,121]. Albeit current epilepsy research has been focusing on these genetically engineered zebrafish, the first zebrafish epilepsy model was induced by 
chemicals [122] and chemically induced zebrafish seizure models are still used nowadays for studying epileptogenesis and discovering novel ASM, e.g., by using pentylenetetraz-ole (PTZ) and ethyl ketopentenoate (EKP) [123-127].

\subsection{Measurement of Seizures in Zebrafish}

Zebrafish larvae are mostly used as a model for epilepsy and seizures due to several advantages, such as high fecundity, leading to numerous fast-developing embryos ex utero allowing researchers to perform easy follow-ups of development and genetic manipulations; possibility for high-throughput analyses using larvae, where each can fit in one well of a 96-well plate; minimal ethical regulations; and relatively low costs for maintenance and housekeeping [121]. However, adult zebrafish are sometimes preferred due to a higher developed neural system, easier handling and certain parameters that sometimes cannot be observed in larvae, e.g., distinct seizure stages [128,129].

\subsubsection{Two-Stage Locomotor and Electrophysiological Setup}

The most accurate and preferred seizure characterization and ASM screening strategy encompasses a two-stage locomotor and electrophysiological setup in zebrafish larvae, rather than adult zebrafish, due to the aforementioned advantages of these larvae [120,121,123].

The locomotor activity is a behavioral assay usually assessed using an automated tracking system in which a 96-well plate can be fitted. Different locomotor read-outs can be obtained, such as total movement [130], total distance in large movements [131] and distance travelled and mean velocity of swim movement [132]. As an illustration, the significantly higher locomotor activity in genetically manipulated mutants than wildtype controls can indicate seizure-like activity. The 96-well plate allows an easy repetition of experiments to be performed; further, diverse compounds can be tested in one single experiment, always compared to a proper control. A decrease in locomotor activity elicited by a certain compound, compared to the vehicle-treated controls, suggests an antiseizure effect. Similar to experiments in rodent epilepsy models, it is of utmost importance to use a sufficiently large group of controls and treated larvae. In addition, one should repeat the locomotor experiment at least once to avoid biological variation among other sources of variation [126,131,133-136]. Unfortunately, this statically appropriate strategy [137] has not been established in each zebrafish laboratory (e.g., [138]). Moreover, some researchers that focus on ASM discovery only perform locomotor experiments without any electrophysiological confirmation (e.g., [139]), which can lead to false positives, for example, in the case of sedatives or muscle-relaxants, and underlines the need to confirm an antiseizure effect by electrophysiological experiments. These experiments usually enclose local field potential (LFP) recordings by which brain activities are recorded from a single electrode in a small part of the brain $[126,140]$. However, LFP recordings have some limitations, since there is no spatiotemporal resolution and a relatively long duration $(10 \mathrm{~min})$ is needed for each recording per zebrafish larva, which contrasts with the high-throughput locomotor experiments. Therefore, several research groups [112,126,127,141-143] have explored other strategies to record brain activity in a relatively easier, more straight-forward and faster manner, as depicted in Table 1.

Even though we underline that the above-mentioned paired selection criterion (locomotor and brain activity assays) is validated in zebrafish epilepsy research, it is different from the clinical setting where ASM can suppress seizures without reducing epileptic events on the electroencephalogram [144,145]. 
Table 1. Different approaches to assess brain activity in zebrafish larvae. Abbreviations: LFP, local field potential; iZAP, integrated Zebrafish Analysis Platform.

\begin{tabular}{ccccc}
\hline & LFP & iZAP & $\begin{array}{c}\text { Multi-Electrode } \\
\text { Array }\end{array}$ & Bioluminescence \\
\hline $\begin{array}{c}\text { Number of } \\
\text { zebrafish larvae } \\
\begin{array}{c}\text { Possible } \\
\text { recording time } \\
\text { Areas of }\end{array}\end{array}$ & 1 & Multiple & 1 & Multiple \\
neuronal activity & 1 & Hours & Days & Days \\
\hline
\end{tabular}

\subsection{2. iZAP and Multi-Electrode Array}

The integrated Zebrafish Analysis Platform (iZAP), constructed by Hong et al. [142] is a novel multichannel electrophysiology unit that can measure brain activities of multiple zebrafish larvae at once. Additionally, there are several loading chambers that allow treatment to be administered over several days and replenishment of the medium to be performed. Furthermore, four extra electrodes per zebrafish larva can record other electrical events, i.e., electro-encephalography, electrooculography, electromyography and audiology. With this in mind, Meyer et al. [143] developed a new microarray recording method, which makes it possible to record up to 61 locations of the zebrafish larval head. This method allows multiregional, synchronous (seizure) brain activity to be detected and can be used for long-term recordings up to ten days.

\subsubsection{Bioluminescence and Fluorescence Calcium Imaging}

Neuronal activity can be assessed in freely swimming zebrafish larvae using bioluminescence [146]. Transgenic zebrafish expressing green fluorescent protein (GFP)-apoAequorin $\left(\mathrm{Ca}^{2+}\right.$-sensitive bioluminescent photoprotein) under the control of the elavl3 promoter exhibit neuronal expression of apoAequorin (transgenic Tg(elavl3:eGFP-apoAequorin) zebrafish). After $24 \mathrm{~h}$ coelenterazine treatment, the luminescence intensity corresponds to the brain activity. This approach has been validated by the proconvulsant, EKP, that resulted in a statistically significant increase in the average light signal. EKP acts as an inhibitor of glutamic acid decarboxylase, thereby hampering the conversion from glutamine into $\gamma$-aminobutyric acid (GABA), which results in relatively more excitation [127]. Other researchers, using a different transgenic zebrafish model (Tg(elavl3:GCaMP6s)), demonstrated that genetically encoded calcium indicators combined with two-photon imaging could accurately report epileptic brain activities [112,141]. Accordingly, it is feasible to outcross the aforementioned transgenic zebrafish with any genetic zebrafish model of epilepsy to examine epileptiform brain activities.

\section{The Wolfram Syndrome (WS)}

\subsection{Physiopathology of the WS}

The Wolfram syndrome (OMIM \#222300) was first described by Wolfram and Wagener [147], who reported four juvenile-onset diabetes with optic nerve atrophy. The acronym DIDMOAD [148] summarizes the most frequent symptoms, i.e., Diabetes Insipidus, Diabetes Mellitus, optic atrophy and deafness. Additional symptoms include renal and vesical dysfunctions [149], peripheral neuropathy [150], mental retardation and psychiatric illness [151] (Figure 1). This pathology is fatal and death occurs at the median age of 35 years, with severe neurological disabilities, including apneic spells, organic brain syndrome or dementia, or bulbar dysfunction. Death is most often due to central respiratory failure [152].

WS is a very rare autosomal-recessive disease. Its prevalence is $1 / 770,000$ [148], with an extremely high heterogeneous prevalence among populations $-1 / 500,000$ in the pediatric population of the United Kingdom [153], 1/710,000 in Japan [154], 1/100,000 in North America [155] and 1/68,000 in Lebanon [156]. Two types of this genetic disorder have 
been identified, Wolfram syndrome 1 (WFS1) and Wolfram syndrome 2 (WFS2) [157,158]. The classical form of WS is caused by mutations of both alleles of the nuclear WFS1 gene, located on chromosome $4 \mathrm{p} 16.1$. The gene of 8 exons (33.4 Kb of genomic DNA) encodes a transmembrane protein of 890 amino acids called Wolframin, localized in the endoplasmic reticulum (ER) [158-161]. Wolframin is a hydrophobic and tetrameric protein with nine transmembrane segments and large hydrophilic regions at both termini [162]. Similar to the many membranous ER proteins $[163,164]$, the localization of WFS1 facilitates its function as a component of the unfolded protein response (UPR). It also maintains ER homeostasis, notably in pancreatic $\beta$-cells [165], by inducing cation channel activity on ER membranes [166] and regulating calcium levels in ER [167,168].

WFS1 is rather ubiquitously expressed in human adults, in a variety of tissues such as heart, brain, placenta, lung, liver, skeletal muscle, kidney and pancreas $[158,159]$. In mice brain, WFS1 gene expression levels are higher in brain structures related to emotions or learning and memory, as shown by a very strong expression of WFS1 in central amygdala and ventral striatum. A strong WFS1 expression was also detected in the hippocampal CA1 region, parasubiculum, the superficial part of the second and third layers of the prefrontal cortex and proisocortical areas, hypothalamic magnocellular neurosecretory system and central auditory pathway. WFS1 expression has been detected in numerous brainstem nuclei and in laminae VIII and IX of the spinal cord. WFS1-positive nerve fibers were found in the medial forebrain bundle, reticular part of the substantia nigra, globus pallidus, posterior caudate putamen, lateral lemniscus, alveus, fimbria, dorsal hippocampal commissure, subiculum and in the central sublenticular extended amygdala, compact part of substantia nigra and ventral tegmental area [169].

Alterations in its quality or quantity are at the origin of many human pathologies, such as certain types of diabetes or neurodegenerative diseases. Indeed, WFS1-deficiency increases endoplasmic reticulum stress, impairs cell cycle progression and triggers the apoptotic pathway specifically in pancreatic $\beta$-cells, leading to diabetes mellitus $[165,170-173]$. WFS1-deficient mice recapitulate several aspects of the neurological manifestations of WS, such as impaired behavioral adaptation to stress including elevated levels of serum corticosterone upon exposure to stress [174-176], stress-induced depressive behavior [177] and alterations in visual function, especially the retina [178].

El-Shanti et al. [179] identified a potential second locus, designed WS2 (OMIM \#604928), which maps to chromosome 4q22-24. This disorder is due to mutations of the CISD2 gene [157]. The CISD2-encoded protein, an ER intermembrane small protein (ERIS), is a zinc finger that localizes to the ER and regulates the UPR and $\mathrm{Ca}^{2+}$ homeostasis, as well as autophagy $[157,180]$. Patients with WS2 gene mutation develop the same symptoms except diabetes insipidus [181]. However, they present other symptoms, such as profound upper gastrointestinal ulceration, bleeding and defective platelet aggregation [182-184]. 


\section{WOLFRAM SYNDROME}

HUMAN
Diabetes mellitus
Optic atrophy
Deafness
Diabetes insipidus
Neurological disorders
ER stress, calcium homeostasis and mitochondrial
alteration

ZEBRAFISH

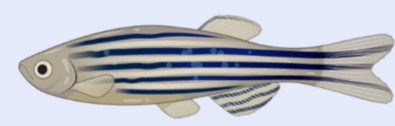

wfs 1 deletion

?

Visual deficit (VMR, wfs 1ab ${ }^{\text {Ko. }}$ OKR, wfs $1 b^{\text {W493X) }}$ ) and decrease of photoreceptors number : rods (wfs1 ${ }^{\text {c825X }}$, wfs $1 a b^{K O}$ ) and cones ( $w f 1 a b^{K O}$ )

No hearing loss (ASR, wfs 1a $a^{c 825 X}$, wfs 1 $b^{\text {w493X }}$, wfs1 $a b^{\text {Ko }}$ )

?

Increased anxiety (wfs1ab ${ }^{k O}$ )

Mitochondrial activity (wfs $1 a b^{K O}$ ) and ER stress response alteration ( $w f s 1 a^{c 825 X}, w f s 1 b^{\text {w493X }}, w f s 1 a b^{K O}$ )

Figure 1. WFS1 mutant zebrafish as useful tool to decipher physiopatological deficits induced in Wolfram syndrome patients. The WFS1 gene mutation causes Wolfram syndrome, which is correlated with four main symptoms, i.e., diabetes mellitus, optic atrophy, deafness, diabetes insipidus and neurological disorders. At different cellular levels, these deficits are mainly induced by ER stress response, calcium homeostasis and mitochondrial activity alterations. In zebrafish larvae ( $5 \mathrm{dpf}$ ), these deficits are mostly reproduced; therefore, they mimic human pathology, thus making them a good study model for Wolfram syndrome. Adapted from references [147,150,151,185,186].

\subsection{Modelling of WS in Zebrafish}

As the zebrafish genome is duplicated, the genome contains two different genes, WFS1 $a$ and WFS1b. Therefore, two mutants have been generated by ENU mutagenesis. The first line, WFS1a ${ }^{C 825 X}$, has the WFS1a gene invalidated by the replacement of a cysteine by a stop codon at position 825 . The second line, WFS1b ${ }^{W 493 X}$, has the WFS1b gene invalidated by the replacement of a tryptophan by a stop codon at position 493 . A third mutant line was generated from crossing the two lines to generate the double mutant WFS1a ${ }^{\mathrm{C} 229 \mathrm{X}} \times$ WFS1b ${ }^{\text {W493X }}$, called thereafter WFS1ab ${ }^{K O}$ line, for which both WFS1 genes are invalidated. A first behavioral analysis showed that WFS1b ${ }^{W 493 X}$ zebrafish exhibited a decrease of their visual motor response and optokinetic response [185]. The WFS1ab ${ }^{K O}$ line showed an increased locomotion in visual motor response and in touch escape response, showing visual deficit and/or exacerbated anxiety. Acoustic startle response was unchanged, thus suggesting an absence of hearing loss [186] (Figure 1).

\subsection{WFS1 and Stress Response}

The ER is the compartment in which the proteins are folded with or without the help of chaperone proteins, then matured by post-translational modifications. Signaling pathways are activated when protein folding is inhibited or disturbed and their primary purpose is to decrease protein biosynthesis to reduce the buildup of these proteins in the ER lumen and to increase the biosynthesis of proteins involved in the machinery for the degradation of proteins associated with the ER ("ER-associated degradation", ERAD), increase the biosynthesis of chaperone proteins and, finally, help the ER to recover its 
calcium homeostasis $[163,187,188]$. This set of signaling pathways, which is a physiological adaptive response of the cell to the accumulation of improperly folded proteins, is called UPR and prevents cell damages and apoptotic mechanisms [189-191].

Three signaling pathways are involved in the UPR and are initiated by the dissociation of the binding immunoglobulin protein chaperone (BiP) at its luminal part from three effectors, namely, RNA-activated protein kinase-like endoplasmic kinase (PERK), inositolrequiring kinase 1 (IRE1) and activating transcription factor 6 (ATF6) [192,193]. Under physiological conditions, these proteins are transmembrane proteins of the ER and are maintained in an inactive state by the binding of the chaperone protein BiP to their luminal domain. During an ER stress as unfolded/misfolded proteins accumulate in the ER lumen, $\mathrm{BiP}$ is released from these complexes in order to activate them.

The oligomerization of IRE1 induces an autophosphorylation in the kinase domain that allows the X-box binding protein 1 (XBP1) to perform mRNA splicing and form sXBP1, which up-regulates UPR genes [194]. Due to its endonuclease activity, IRE1 also induces degradation of mRNAs localized in the ER membrane in order to decrease their translation by a mechanism called regulated-IRE1 dependent decay (RIDD) [195]. Similar to IRE1, the oligomerization of PERK induces an autophosphorylation and directly phosphorylates the eukaryotic initiation translation factor $2 \alpha$ (eIF2 $\alpha$ ), which leads to the attenuation of general protein translation. This reduces the ER workload and protects cells from apoptosis by ER stress [196,197]. Paradoxically, the translation of certain mRNAs is increased similarly to the activating transcription factor 4 (ATF4) [198], which plays an important role in the activation of the genes involved in amino acid metabolism, autophagy, antioxidant response and apoptosis. Indeed, ATF4 activates the transcription of target genes encoding the C/EBP homologous protein (CHOP) [199]. Deregulated CHOP activity compromises cell viability and cells lacking CHOP are significantly protected from the lethal consequences of ER stress [200,201]. Furthermore, phosphorylated eIF2 $\alpha$ increases the apoptosis antagonizing transcription factor (AATF), that works as a transcription cofactor regulating pro-survival genes under certain conditions of cell stress [202-204]. PERK also phosphorylates NRF2, an antioxidant response transcription factor.

Under conditions of ER stress, ATF6 is translocated from the ER to the Golgi apparatus, where it is cleaved at two sites by site-1 (S1P) and site-2 (S2P) proteases [205]. The Nterminal domain of ATF6 migrates to the nucleus where it binds to sequences called endoplasmic reticulum stress response element (ERSE), in order to activate genes encoding ER chaperones, ERAD components and XBP1 [206-208].

Due to its location at the ER membrane, WFS1 has a function in ER homeostasis, more particularly as a negative regulator of the UPR pathway. In physiological condition, WFS1 plays a crucial role in regulating ATF6 $\alpha$ transcriptional activity through HRD1mediated ubiquitination and proteasome-mediated degradation of ATF6 $\alpha$ protein [161]. Indeed, the cleaved form of ATF6 translocates to the nucleus and the non-cleaved form of ATF6 is degraded $[209,210]$. In ER stress conditions, ATF6 $\alpha$ detaches from WFS1 and regulates stress signaling targets in the nucleus. As ER homeostasis is restored, WFS1 expression is induced, which results in the degradation of ATF6 $\alpha$ [210]. In WS, WFS1 is not functional due to its mutation. ATF6 $\alpha$ is no longer degraded via WFS1; therefore, it is hyperactivated regardless of emergency stress conditions, leading to the death of pancreatic $\beta$ cells. WFS1-deficiency also attenuates the AATF-Akt1 pathway and might be involved in the observed $\beta$-cell death [204]. Finally, it was seen that, in SH-SY5Ycells transfected with an XBP1-expressing vector, the WFS1 gene is overexpressed indirectly through an ERSE-like sequence in its promoter and by XBP1 [170]. Indeed, when XBP1 is present in excess, WFS1 can lower the levels of XBP1S, thus regaining ER homeostasis. Therefore, the role of WFS1 in the regulation of ER stress revealed some issues, but studies must be carried out to understand its global implication in this cellular protection mechanism.

The characterization of the three mutant zebrafish lines highlights deficits in some ER stress pathways as a function of the loss of WFS1 functionality [185,186]. The expression of the different protein factors involved in the three major ER stress pathways (IRE1, 
PERK and ATF6) were studied by quantitative polymerase chain reaction (qPCR) on $5 \mathrm{dpf}$ zebrafish larvae in basal condition or after induction of ER stress using tunicamycin ( $2 \mu \mathrm{g} / \mathrm{mL}$ for $24 \mathrm{~h}$ at $4 \mathrm{dpf}$ ), which induces ER stress indifferently through the three ER stress pathways blocking N-linked glycosylation with transfer inhibition of UDP-Nacetylglucosamine to dolichol phosphate in the ER of eukaryotic cells, thus disrupting protein maturation [211-213].

The WFS1a ${ }^{C 825 X}$ line showed, in basal condition, a decrease in bip and atf $4 \alpha$ mRNA levels and a decrease in hsp90b1 and chop mRNA levels in ER stress condition [185], suggesting that only the PERK pathway is impacted after WFS1a invalidation. However, the WFS $1 b^{W 493 X}$ line showed decreased bip, ire 1 and $x b p 1 s$, compared to controls in basal conditions. After tunicamycin treatment, altered increases in bip, ire 1, perk, $x b p 1 s, x b p 1 u s$, eIf 2 and chop levels were noted [185], clearly showing alteration in the IRE1 and PERK pathways in the mutated WFS1b line, while the Atf6 pathway remained unaffected. Interestingly, the WFS $1 a b^{K O}$ line only presented marked alterations in bip and hsp90b1 levels, suggesting that ER stress detection may be altered but the UPR remains functional after complete invalidation of WFS1a and WFS1b in zebrafish [186] (Figure 1).

Therefore, the WFS $1 b^{W 493 X}$ line is the most adequate line to mimic the alteration of ER stress response found in WS, as the UPR response is consistently impacted on both the IRE1 and PERK pathways (Figure 1).

Notably, zebrafish offer the possibility to visualize the activation of ER stress in vivo. Indeed, transgenic animals were constructed in order to detect the activation of the different signaling pathways. Concerning the IRE1 pathway, a transgenic zebrafish expressing a part of the cDNA of xbp1 fused to GFP was generated, thus allowing the splicing of xbp1 after the activation of IRE1. This led to the production of a xbp1-GFP protein [214] that allowed the IRE1 pathway to be monitored. Concerning the ATF6 pathway, a transgenic zebrafish expressed five repeated ATF6 consensus binding site upstream of a minimal $c$-fos promoter driving eGFP or d2GFP. Therefore, when ATF6 is activated, it binds to its binding sites and activates the production of eGFP [215]. Finally, concerning the PERK pathway, a transgenic zebrafish expressing a human ORFCHOP fused to GFP. Therefore, when PERK is activated, ATF4 expression is induced and CHOP-GFP is produced, allowing the PERK activated pathway to be visualized [216].

\subsection{WFS1 and $\mathrm{Ca}^{2+}$ ER Homeostasis}

Mitochondria are complex intracellular organelles, responsible for ATP production, as well as various metabolic cofactors ( $\mathrm{NADH}$ and $\left.\mathrm{FADH}_{2}\right)$, and are involved in different processes such as communication, differentiation, apoptosis and regulation of the cell cycle. Mitochondrial dysfunction has been linked to many neurodegenerative disorders such as Alzheimer's disease, Parkinson's disease, amyotrophic lateral sclerosis or Huntington's disease, which are disabling and often fatal [217-219]. The inositol 1,4,5-trisphosphate receptor (IP3R) is responsible for $\mathrm{Ca}^{2+}$ release from the ER to the mitochondria, particularly at ER-mitochondria junctions, called MAMs, for mitochondria-associated membranes [220] and composed of a large number of proteins ensuring their structure and functionality [221]. Once $\mathrm{Ca}^{2+}$ is released from the ER, it enters mitochondria through the voltage-dependent mitochondrial transmembrane anion channel (VDAC1), whose permeability is controlled by ATP and other regulatory factors [222]. The IP3R/VDAC1 complex is stabilized by the molecular chaperone glucose-regulated protein 75 (GRP75) [223]. Series of chemical reactions are essential to maintain a robust amount of ATP and metabolic intermediates or building blocks for the generation of fatty acids, amino acids and nucleotides, allowing the cells to enter the cell cycle, proliferate and keep normal homeostasis.

The neural $\mathrm{Ca}^{2+}$ sensor-1 (NCS1) has been reported to regulate the IP3R [224]. It is a small protein $\left(22 \mathrm{kDa}\right.$ ) with four EF-hand motifs (including three of which that bind to $\mathrm{Ca}^{2+}$ ), essential for the release of neurotransmitters [225], synaptic plasticity [226,227], learning and memory [226,228], neurite growth [229] and neuronal survival [230]. In physiological condition, WFS1 interacts with NCS1 [231,232] and prevents NCS1 degradation by binding 
to it and forming a complex with IP3R to activate ER-mitochondria $\mathrm{Ca}^{2+}$ transfer. When the WFS1/NCS1/IP3R complex and VDAC1 are functional, $\mathrm{Ca}^{2+}$ can properly transfer from the ER to mitochondria and activate the TCA cycle and mitochondrial respiratory chain. In WS, WFS1 is no longer functional and the complex WFS1/NCS1/IP3R loses its effectiveness, leading to NCS1 degradation and a decrease in ER-mitochondria $\mathrm{Ca}^{2+}$ transfer. The MAM fraction is a potential therapeutic target because many neurodegenerative diseases and, more precisely, those of WS, which interest us in this study, have a deficit of MAM, as well as significant ER stress.

A significant amount of information regarding calcium signaling during development in animal models has come from studies on zebrafish [233]. Indeed, the zebrafish embryo is transparent and small and ex utero maturation facilitates the visualization of calcium signals within the whole organism. In addition, its availability of genetically encoded calcium indicators and light-sheet microscopy allowed Ahrens et al. [234] and Panier et al. [235] to image the activity of large numbers of neurons in the brains of zebrafish. The advances in imaging technology $[234,236]$, the processing of the generated data $[237,238]$ and the engineering of encoded calcium indicators [239], allow the activity of a large number of cells on a whole and living organism, such as activation of neuronal circuits in zebrafish, drosophila and mouse, to be measured [240,241].

According to the principle of electrical excitation cells, calcium influx is increased via voltage-gated calcium ion channels, which can be monitored and made visible by calcium imaging using fluorescent calcium probes.

Interestingly, we could imagine, for our study, to analyze the impact of WFS1 mutation on calcium influx in different cell types affected by WS. By the principle of the GCaMP and Gal4 system widely used today in zebrafish [242,243], it would be enough to create transgenic fish expressing the modified yeast transcription factor Gal4 in specific cell types that degenerate in WS patients. Thus, once the deficit has been measured on these different cell types, testing molecules that would potentially restore these calcium pathways and in fine restore cellular calcium homeostasis.

Similar to the analysis of ER stress, $\mathrm{Ca}^{2+}$ imaging is feasible in vivo in zebrafish due to the availability of different transgenic zebrafish expressing GcAMP. Notably, different lines were created in D. Raible's lab to analyze the $\mathrm{Ca}^{2+}$ variation following IP3R stimulation in the ER, cytoplasm and mitochondria of the hair cells of the lateral line [244].

\section{The Dravet Syndrome (DS)}

\subsection{Physiopathology of DS}

Dravet syndrome (DS) is one of the most severe epilepsy syndromes and accounts for up to $6 \%$ of the epilepsy cases with onset during infancy. It is named after Dr Charlotte Dravet, who first described this syndrome in 1978. This syndrome is highly characterized by drug-resistant seizures, several physical, intellectual and behavioral comorbidities and a relatively high mortality rate [245] (Figure 2).

\subsubsection{Genetics}

Almost $90 \%$ of DS patients carry a SCN1A mutation, which is also the most prominent epilepsy gene in general. The SCN1A gene codes for the Nav1.1 sodium ion channel, which is expressed throughout the central nervous system (CNS). Even though most genetic mutations are de novo, it is highly recommended for parents to have genetic counseling and genetic examination due to the possibility of parental mosaicism. Regarding genotypephenotype correlations, truncating mutations seems to be associated with more severe phenotypes than missense mutations. However, the genotype does not appear to be useful in clinic to predict prognosis or choose the proper therapy [245].

\subsubsection{Features}

During the first year of life, generalized and unilateral seizures, often related to fever episodes, occur in an otherwise healthy child [246-248]. These seizures can be 
clonic or tonic-clonic and are later associated with myoclonus, focal seizures and atypical absences [249]. In the second or third year of life, a decline in neurodevelopmental abilities can be noted and this becomes more evident in adolescence [250]. Other comorbidities can be evident, such as motor problems (e.g., ataxia and gait disturbances) and sleeping problems [251]. Therefore, it is not surprising that the quality of life (QoL) is relatively lower in DS children [245]. Furthermore, the mortality rate is relatively high, with sudden unexpected death in epilepsy (SUDEP) as major cause ( $>60 \%$ of the cases) in teenagers [252] or early adulthood [253].

\subsubsection{Brain Anomalies}

Brain magnetic resonance imaging (MRI) studies in DS patients usually do not show any anomalies and MRI appears to be normal at epilepsy onset [245,254]. Nevertheless, in a small minority of the patients, structural brain anomalies can be found, e.g., cortical dysplasia, cerebral atrophy, or hippocampal sclerosis [255]. In addition, Lee and colleagues [256] found a reduction in several brain structures, such as gray and white matter, as well as in cerebellar white matter, subcortical volumes and mean cortical thickness. Furthermore, thinning of the corpus callosum, nodular heterotopia and cerebral, cerebellar and hippocampal atrophies were reported in a few DS adolescents [250]. The origin of these brain anomalies is uncertain and does not seem to correlate with epilepsy duration or severity. It is possible that the dysfunctional SCN1A gene confers a unique vulnerability to the brain, which should be investigated in prospective human studies $[250,255]$ and animal models of DS (see Section 4.2.3).

\subsection{Modelling of DS in Zebrafish (Scn1a Mutants)}

Zebrafish scn1a mutants (homozygous scn1lab ${ }^{-/-}$mutant zebrafish larvae; hereafter referred to as DS zebrafish) were first identified by Schoonheim et al. [257] in an ENU mutagenesis screen. They named these mutants double indemnity (didy; didy ${ }^{5552}$ mutants) zebrafish and described a defect in saccades during optokinetic responses. Three years later, Baraban et al. [138] described an epileptic phenotype in these scn1lab ${ }^{-/}$mutant zebrafish, which are now established as the zebrafish model of DS [126,131,135,258,259].

\subsubsection{Genetics}

The aforementioned DS zebrafish carry two alleles with a point mutation (AG3632G). This mutation leads to the conversion of a thymine (AT3632G, wildtype) into a guanine (AG3632G, mutant), which transforms a methionine into an arginine. Subsequently, this transformation results in a loss of function, similar to the situation in humans with DS [260]. Even though most DS patients are heterozygous for the SCN1A mutation, only the homozygous scn1lab ${ }^{-1-}$ mutant zebrafish larvae mimic DS features. This apparent discrepancy might be due to the teleost whole genome duplication [261] that resulted in two zebrafish genes homologous to SCN1A, scn1laa and scn1lab. Therefore, a homozygous mutation in one of these genes equals to the heterozygous state in DS patients. The epileptic phenotype of these stable didy mutants was also observed in a transient zebrafish model of DS by an MO knockdown (KD) of the scn1lab gene. Moreover, using this MO KD model, we were the first to show the efficacy of fenfluramine (FA) [262], which is now approved for the treatment of DS patients [263]. FA's efficacy in DS treatment was also confirmed in stable didy mutants $[131,258]$. Additionally, another stable mutant was created, i.e., homozygous scn1laa ${ }^{-/-}$mutants, that show a similar epileptic phenotype as homozygous scn1lab ${ }^{-/-}$ mutants [132]. 


\section{DRAVET SYNDROME}

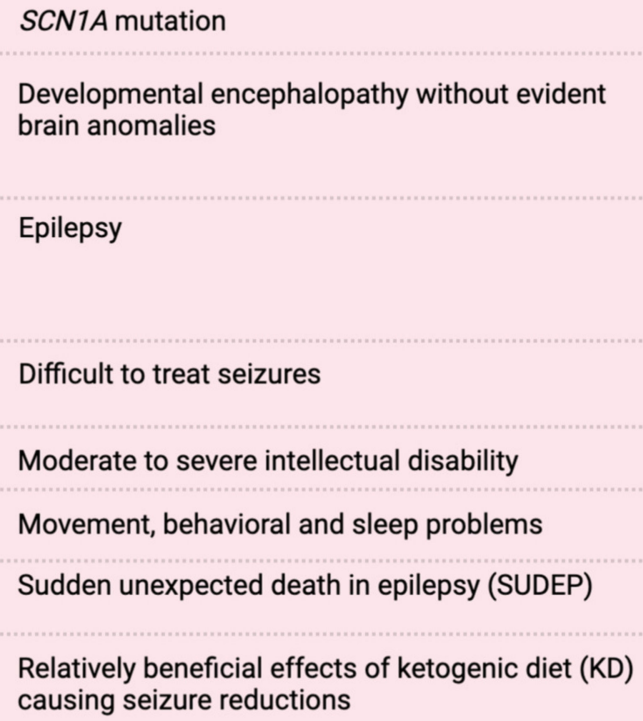

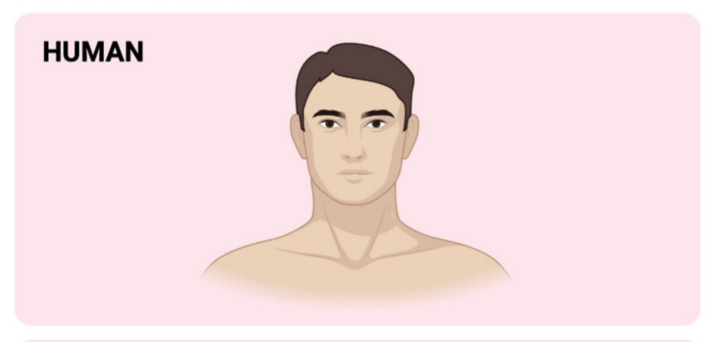

\section{ZEBRAFISH}

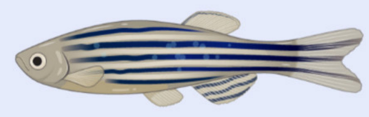

Scn1a mutation (homozygous scn1Lab mutants)

Evident brain anomalies: Reduced arborization of inhibitory GABAergic neurons and defects in neurotrasmitter contents, synaptic balance and neuronal apoptosis

Epileptiform activities: Recurrent and spontaneous seizure-like behavior and epileptiform brain discharges (also homozygous scn1Laa mutants )

Drug-resistant seizures (also homozygous scn1Laa mutants)

$?$

Anxiety, movement disorders, sleep-wake cycle disturbances

Die prematurely around 9-14 dpf

Glucose and mitochondrial hypometabolism. Beneficial effect of KD and PK11195 that increases gluconeogenesis

Figure 2. Scn1a mutant zebrafish as useful tool to decipher physiopatological deficits induced in Dravet syndrome patients. The SCN1A gene mutation causes Dravet syndrome, which is correlated with several symptoms and is referred to as a "developmental encephalopathy with epilepsy". In zebrafish larvae (from $3 \mathrm{dpf}$ onwards), these deficits are mostly reproduced; therefore, they mimic human pathology, thus making them a good study model for Dravet syndrome. Adapted from references [117,131,132,135,138,260,264-267].

Interestingly, scn1lab shares $76 \%$ identity to the human SCN1A, while scn1laa only shares $67 \%$ identity [268]. Moreover, homozygous scn1lab ${ }^{-/}$mutants can phenotypically be distinguished from wildtype by their darker appearance, the absence of a swim bladder and a slight body curvature [138], which is not the case for homozygous scn1laa ${ }^{-1}$ mutants. Thus, this relatively higher identity percentage and distinct phenotype has boosted the use of scn1lab ${ }^{-/}$mutants as a zebrafish DS model [117,142,145,250,264,269-271]. The reason of this darker pigmentation could be the upregulation of melanocortin $5 \mathrm{a}$, although the exact meaning of this upregulation remains unknown [138].

\subsubsection{Features}

Similar to humans, DS zebrafish exhibit recurrent and spontaneous seizure-like behavior (locomotor) and epileptiform brain discharges (LFP) from $3 \mathrm{dpf}$ onwards, until they die prematurely around 9-14 dpf (Figure 2).

Several genes appeared to be up- and downregulated in DS zebrafish, although many of the identified genes did not have an evident CNS-related expression and/or function [138]. In addition, the downregulation of five glycolytic genes, a significant decrease in baseline glycolytic rate and oxygen consumption rate have been observed in DS zebrafish, suggesting that glucose and mitochondrial hypometabolism might contribute to DS pathogenesis [269,270]. Furthermore, Grone et al. [265] confirmed DS comorbidities in DS zebrafish, such as anxiety, movement disorders and sleep-wake cycle disturbances. 


\subsubsection{Brain Anomalies}

Further research into the mechanistic features of the loss of function of SCN1A is possible thanks to different DS animal models. DS zebrafish have dynamic changes in progenitor cell and glial population in the CNS and show a reduced arborization of inhibitory GABAergic neurons [117]. Not only GABA, but also other neurotransmitters, such as serotonin (5-HT) and the excitatory neurotransmitter glutamate, could play a role in DS pathogenesis [131,135]. Likewise, there appears to be a defective synaptic balance between excitation and inhibition in DS zebrafish, as well as increased apoptosis of neurons [264]. The exact meaning of these CNS anomalies deserves further research and could boost ASM discovery in these DS zebrafish. For example, the pck1 activator PK11195 increases gluconeogenesis and reduces seizures in DS zebrafish [269] (Figure 2).

\subsection{DS Zebrafish Mimicking Drug-Resistant Seizures}

The spontaneous seizures of DS zebrafish do not respond sufficiently to numerous ASM, although valproate and several GABAergic compounds, e.g., benzodiazepines and stiripentol, are effective [138]. This poor response to ASM is comparable to the drugresistant seizures in DS patients [272]. Following the guidelines of the North American consensus panel and the European expert group, clinicians should consider valproate as the first ASM in DS. If no sufficient seizure reduction has been obtained, add-on treatment by ASM include topiramate, stiripentol with or without clobazam, cannabidiol, or FA [244]. Even though DS patients are usually treated by a combination of ASMs, we are presently the only zebrafish group confirming the efficacy of combinatorial ASM treatment in DS zebrafish [250], while others only tested one ASM at a time [138,140] (Figure 2).

\subsection{DS Zebrafish for Drug Discovery}

Due to the drug-resistant nature of seizures in DS zebrafish, effective compounds in this model could not only be effective for treating DS but also seizures related to other severe epilepsy syndromes. For instance, FA was not only active in DS patients but also showed great potential for treating seizures in patients with Lennox-Gastaut syndrome [273] and Sunflower syndrome [274].

Before testing any compound in zebrafish, one should determine the maximum tolerated concentration (MTC), since a toxic or lethal concentration could falsely be reported as a seizure-reducing agent. The MTC can be defined as the maximum concentration for which 12 out of 12 zebrafish larvae do not exhibit any signs of toxicity after a $48 \mathrm{~h}$ treatment. These toxicity signs can be observed under the microscope, such as a decreased or absent touch response, body deformations, edema, posture loss, anomalies in heart rate or circulation and death [131]. If compounds are randomly tested at arbitrarily chosen concentrations, as done by other groups [138], this could lead to false positives (Figure 2).

\subsubsection{Trazodone, TCB-2 and Lisuride}

The first drug screening in DS zebrafish by Baraban's laboratory led to the discovery of clemizole and their radioligand agonist assays showed that clemizole likely is a $5-\mathrm{HT}_{2 \mathrm{~A}}$ receptor $\left(5-\mathrm{HT}_{2 \mathrm{~A}} \mathrm{R}\right)$ and $5-\mathrm{HT}_{2 \mathrm{~B}} \mathrm{R}$ agonist [132]. In striking contrast, they investigated the antiseizure effects of trazodone, which is a $5-\mathrm{HT}_{2 \mathrm{~A}} \mathrm{R}$ antagonist, thus not an agonist $[275,276]$. Our research study using the same DS zebrafish-but with a fundamentally different and validated protocol-has shown that $5-\mathrm{HT}_{2 \mathrm{~A}} \mathrm{R}$ agonists are effective seizure-reducing agents. We used the highly selective 5- $\mathrm{HT}_{2 \mathrm{~A}} \mathrm{R}$ agonists, TCB-2 [131] and NBOH-2C-CN [135], instead of non-selective compounds such as trazodone that also affect other receptors and transporters [266]. Even though TCB-2 could be hallucinogenic-thus, not appropriate as an ASM candidate-novel insights revealed a biased 5- $\mathrm{HT}_{2 \mathrm{~A}} \mathrm{R}$ phosphorylation in response to hallucinogenic versus non-hallucinogenic agonists [277]. This finding paves the way to repurpose non-hallucinogenic $5-\mathrm{HT}_{2 \mathrm{~A}} \mathrm{R}$ agonists for $\mathrm{DS}$ treatment, such as lisuride [126], which has already been safely used to treat pediatric and adult patients with Parkinson's disease, migraine and cortical reflex myoclonus [267,278-280]. 
Since GABAergic interneurons show severe impairments in DS pathophysiology [281,282], the modulation of GABAergic neurotransmission could play a role in DS treatment. Of importance, 5- $\mathrm{HT}_{2 \mathrm{~A}} \mathrm{R}$ agonism seems to facilitate GABAergic neurotransmission, which could explain the efficacy of 5- $\mathrm{HT}_{2 \mathrm{~A}} \mathrm{R}$ agonism for DS treatment [283] and other forms of epilepsy [284-286]. While these studies highlight the potential of $5-\mathrm{HT}_{2 \mathrm{~A}} \mathrm{R}$ agonism in epilepsy treatment, others have shown that 5- $\mathrm{HT}_{2 \mathrm{~A}} \mathrm{R}$ stimulation could even reduce SUDEP [287-289]. Buchanan and colleagues demonstrated that the aforementioned $5-\mathrm{HT}_{2 \mathrm{~A}} \mathrm{R}$ agonist, TCB-2, not only reduces seizures but also lowers seizure-induced mortality in Lmx $1^{\text {bf } / \mathrm{f} / \mathrm{p}}$ mice- that lack over $99 \%$ of CNS 5-HT—in acute pilocarpine and maximal electroshock seizure (MES) models. Overall, a plethora of research works underline the beneficial effects of 5- $\mathrm{HT}_{2 \mathrm{~A}} \mathrm{R}$ agonism in treating epilepsy and potentially reducing SUDEP. Therefore, the questionable findings of trazodone, a $5-\mathrm{HT}_{2 \mathrm{~A}} \mathrm{R}$ antagonist, should be considered carefully.

\subsubsection{Lorcaserin}

We were the first to discover that lorcaserin, a $5-\mathrm{HT}_{2 \mathrm{C}} \mathrm{R}$ agonist, significantly reduced abnormal behavioral and electrographic seizure activities in DS zebrafish [131]. Subsequently, these results were replicated by Griffin et al. [132], underlining that serotonergic modulation as a pharmacological modality for treating DS was not novel at that time.

Regarding the potential efficacy of this compound in five DS patients, the rather small non-placebo controlled clinical study is difficult to interpret since the exact seizure frequencies are not provided [132]. After three months of treatment, nearly all (four out of five) patients returned to their baseline seizure frequency and only two patients remained on the drug [290]. Therefore, these findings are too preliminary and larger trials are warranted. Nonetheless, ample evidence is available indicating that $5-\mathrm{HT}_{2 \mathrm{C}} \mathrm{R}$ agonists are interesting compounds for treating effectively neurological diseases such as epilepsy [291-295], if they do not stimulate 5- $\mathrm{HT}_{2 \mathrm{~B}} \mathrm{R}$ [296].

\subsubsection{Clemizole and Analogs Stimulating $5-\mathrm{HT}_{2 \mathrm{~B}} \mathrm{Rs}$}

The $5-\mathrm{HT}_{2 \mathrm{~B}} \mathrm{Rs}$ are mainly located in the heart and $5-\mathrm{HT}_{2 \mathrm{~B}} \mathrm{R}$ agonists could lead to drug-induced cardiotoxicity [297-299]. That is why repurposing lisuride for DS treatment holds great promise, since it significantly reduces seizures in the DS zebrafish model [126], acts as a $5-\mathrm{HT}_{2 \mathrm{~B}} \mathrm{R}$ antagonist and thereby is devoid of any cardiotoxic effects [280].

Baraban and colleagues showed the efficacy of clemizole, a $5-\mathrm{HT}_{2 \mathrm{~B}} \mathrm{R}$ agonist and other $5-\mathrm{HT}_{2 \mathrm{~B}} \mathrm{R}$ agonists in DS zebrafish [138]. Whereas 5- $\mathrm{HT}_{2 \mathrm{~B}} \mathrm{R}$ agonists were ineffective in the same zebrafish model $[131,135]$. Two independent research groups $[259,271]$ showed that clemizole was toxic at the concentrations used by Baraban's lab [140]. After a toxicity assessment, they have tried clemizole at lower concentrations and discovered that this compound does not reduce seizures $[259,271]$.

\subsubsection{Fenfluramine}

Based on our DS zebrafish research studies, FA is likely to act via the $5-\mathrm{HT}_{1 \mathrm{D}} \mathrm{R}, 5-$ $\mathrm{HT}_{2 \mathrm{C}} \mathrm{R}$ and $\sigma_{1}$ receptors [135]. FA's seizure reduction was not counteracted by $5-\mathrm{HT}_{2 \mathrm{~B}} \mathrm{R}$ antagonism, indicating that $5-\mathrm{HT}_{2 \mathrm{~B}} \mathrm{R}$ agonism is not responsible for the efficacy of this FDA- and European Medicines Agency (EMA)-approved drug for treating DS. Inevitably, these findings suggest that $5-\mathrm{HT}_{2 \mathrm{~B}} \mathrm{R}$ agonism is not necessary to treat seizures in DS patients. The weak agonistic activity of $\mathrm{FA}$ at $5-\mathrm{HT}_{2 \mathrm{~B}} \mathrm{Rs}$ could be responsible for druginduced valvulopathy, although severe FA-induced cardiotoxicity was only observed when this drug was used as a weight-loss agent at much higher doses and/or in combination with other amphetamine-like drugs [263,297,300,301]. For this reason, clinical trials with low-dose FA monitor cardiac side effects closely and, until now, FA's safety has been guaranteed [302].

Equally important, our DS zebrafish research studies demonstrated the efficacy of a highly selective $5-\mathrm{HT}_{1 \mathrm{D}} \mathrm{R}$ agonist, GR 46611, which was confirmed in a DS mice model 
and even expanded the lifespan in these DS mice [303]. Therefore, one might believe that $5-\mathrm{HT}_{1 \mathrm{D}} \mathrm{R}$ agonistic activities of FA can significantly reduce mortality in DS.

Others have shown that $5-\mathrm{HT}_{2 \mathrm{~A}} \mathrm{R}[304]$ and $5-\mathrm{HT}_{4 / 7} \mathrm{R}[305]$ are also involved in FA's mechanism of action and potentially reduce SUDEP $[305,306]$. Finally, FA can even restore the neuronal cytoarchitecture in DS zebrafish on a cellular level; thus, FA could be an anti-epileptogenic compound [117].

In clear contrast to the antiseizure effects of clemizole that were, up to now, only validated by one zebrafish research group [138], FA has been proven to be an effective ASM in several animal models of epilepsy (rodent and zebrafish) by multiple researchers worldwide [117,131,140,271,305].

Overall, FA is likely a multidimensional ASM via 5-HTR agonism, positive allosteric modulation of $\sigma_{1}$ receptors and maybe other unidentified pathways [307-309]. Taken together, these preclinical data in DS zebrafish provide new avenues for ASM discovery and warrant further exploratory studies in mice and PWEs.

\section{Pros and Cons of Zebrafish Models in a Context of Molecules High-Throughput Screening}

The use of zebrafish as a powerful model to screen drugs in vivo has gained momentum in the past two decades. This small vertebrate organism has emerged as an intermediate model of choice between the low-throughput and costly rodent models and the cellular models, which allow for high-throughput screening to be performed but lack physiological context (Figure 3).

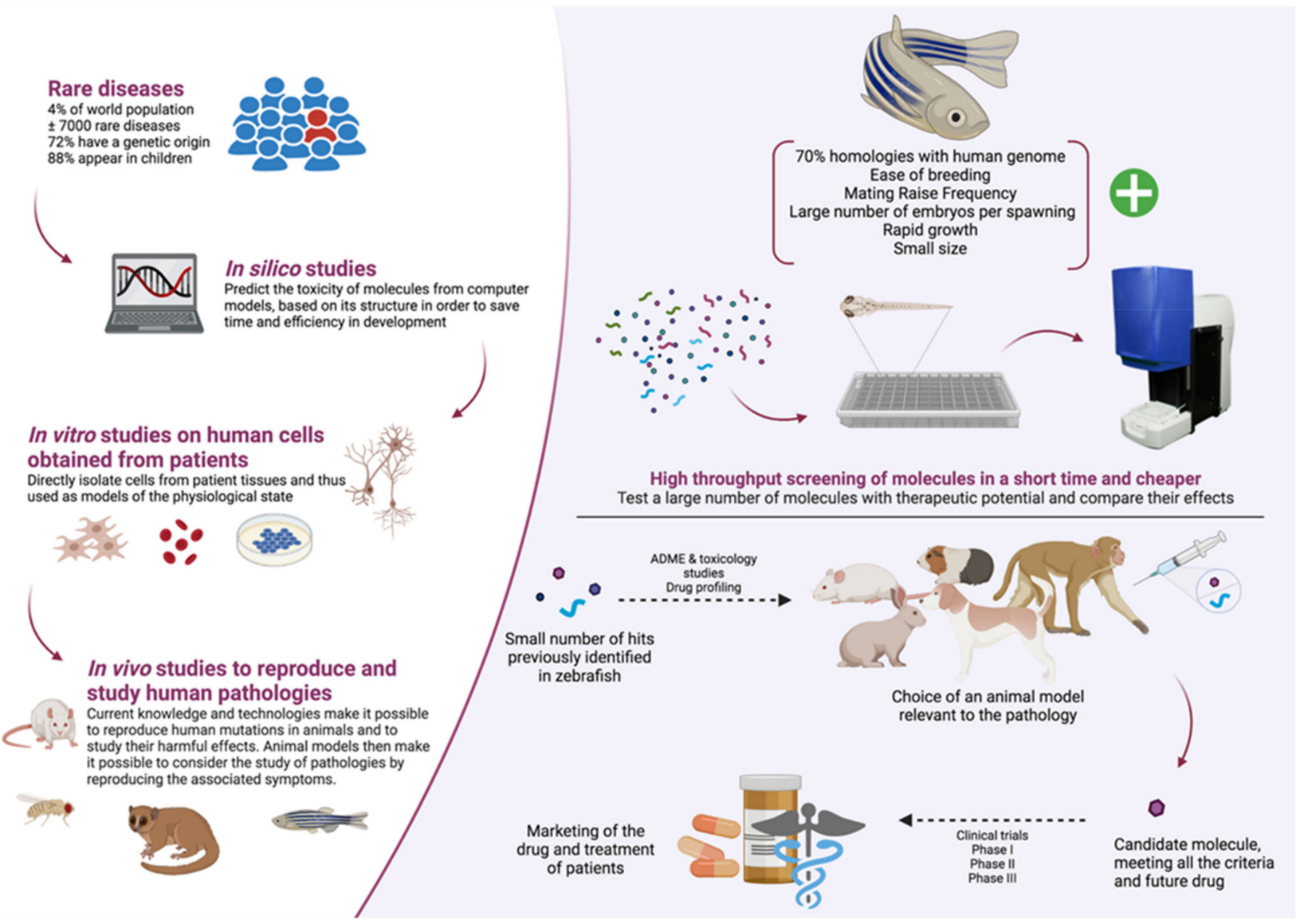

Figure 3. Benefits from the high throughput in vivo screening in zebrafish for the discovery of novel or repositioning drugs in rare genetic diseases. The zebrafish model speeds up studies of rare human diseases to find active molecules to treat associated deficits. The development of a potential future drug involves several stages, often long and expensive. Zebrafish, a useful model that mimics most human pathologies, have shown many advantages for drug development compared to other animal models used. 
The keen interest in this little fish can be explained by its inexpensive husbandry associated with its high fecundity and the easiness of its maintenance, favoring largescale screening. Due to their small size, they can be housed, as adults, in large numbers, but, more importantly, embryos and larvae can be housed in 96-well or 384-well plates, prerequisite for high-throughput analysis protocols.

Drug-induced morphological and developmental defects can be easily experimentally tracked thanks to the transparency of the embryos and the external development of the larvae. In addition, many neurobehavioral phenotypes, such as sleep, addition, learning, vision and hearing, among others, can be quantified using different tracking devices, as described previously, facilitating the study of a given phenotype. In addition, the anatomical and physiological features of zebrafish are relatively similar to the ones in humans. Therefore, zebrafish can be used as a relevant model to study the impact of a given drug on a specific structure or organ.

With the advent of genetic analyses, including next-generation sequencing, a large number of genetic disease causes have been identified, including genes and variants associated with rare diseases [310,311]. Concomitantly, the genetic sequences of the zebrafish genome were published and made accessible [4]. The recent emergence of tools to manipulate the genome combined with the knowledge of both the disease-leading genes in human and the sequences of their zebrafish orthologues is a powerful methodology to create disease-specific models. Zebrafish can be genetically engineered to mimic human mutations, in transient gain or loss of function models (mRNA injection, morpholinos) as well as stable mutant lines (TALENs, CRISPR/Cas9). These methods have been optimized in zebrafish and they have proven to be fast and cost-effective, humanized fish being thus extensively used for targeted drug screening.

Even though zebrafish have emerged as a powerful animal model to study physiopathology of human diseases, some limitations need to be taken into account. Zebrafish are vertebrates and share a lot of morphological similarities with human, as described previously. However, it is crucial to acknowledge that some anatomical divergences may modify the development of the disease in this model, as well as the impact of the tested drugs. As an example, zebrafish do not have a dedicated auditory organ comparable to the inner ear in mammals. The difference was thus circumvented, efficiently, by the study of the hair cells from the lateral line [312]. Therefore, it is important to consider these differences when choosing the zebrafish as an animal model for a given rare disease.

In addition, even though $70 \%$ of human genes have an orthologous gene in zebrafish [4], modifying the expression of these genes to mimic human pathology may lead to a phenotype that would differ from the human one. The analysis would complexify for the $20 \%$ genes that have two orthologs [4]. The duplication of these genes can impede the efficiency of forward or reverse genetic approaches.

Lastly, pharmacokinetic is not as well characterized in zebrafish as it is in mammals. While tremendous efforts have been made recently and the accumulation of pharmacokinetic studies have unraveled new insights (e.g., [313,314]), to pave the way to a more comprehensive understanding of zebrafish pharmacology, more studies are needed. A better understanding of the pharmacokinetics would help optimize the screening protocols as well as allowing researchers to conduct a rapid transfer to mammal models.

Author Contributions: Writing-Original draft preparation, L.C., T.M. and B.D.; writing-review and editing, L.C., E.M.R., J.S., L.L., T.M. and B.D. All authors have read and agreed to the published version of the manuscript.

Funding: This work was supported in part by external resources of the University of Montpellier (Fondation Pour l'Audition FPA RD-2019-13, Retina France Association and Foundation to B.D.). Lucie Crouzier is supported by Association syndrome de Wolfram and the Région Occitanie and Elodie M. Richard by The Snow Foundation and Eye Hope Foundation.

Institutional Review Board Statement: Not applicable.

Informed Consent Statement: Not applicable. 
Data Availability Statement: Not applicable.

Conflicts of Interest: L.L. received grants and is a consultant and/or speaker for Zogenix; LivaNova, UCB, Shire, Eisai, Novartis, Takeda/Ovid, NEL, Epihunter. L.L. has a patent for ZX008 (fenfluramine) for the treatment of Dravet syndrome and infantile epilepsies assigned to his institution and licensed to Zogenix. T.M. received grants and is a consultant and/or speaker for Zogenix, Prilenia. L.C., E.M.R., J.S., B.D. declare no commercial or financial relationships that could be construed as a potential conflict of interest.

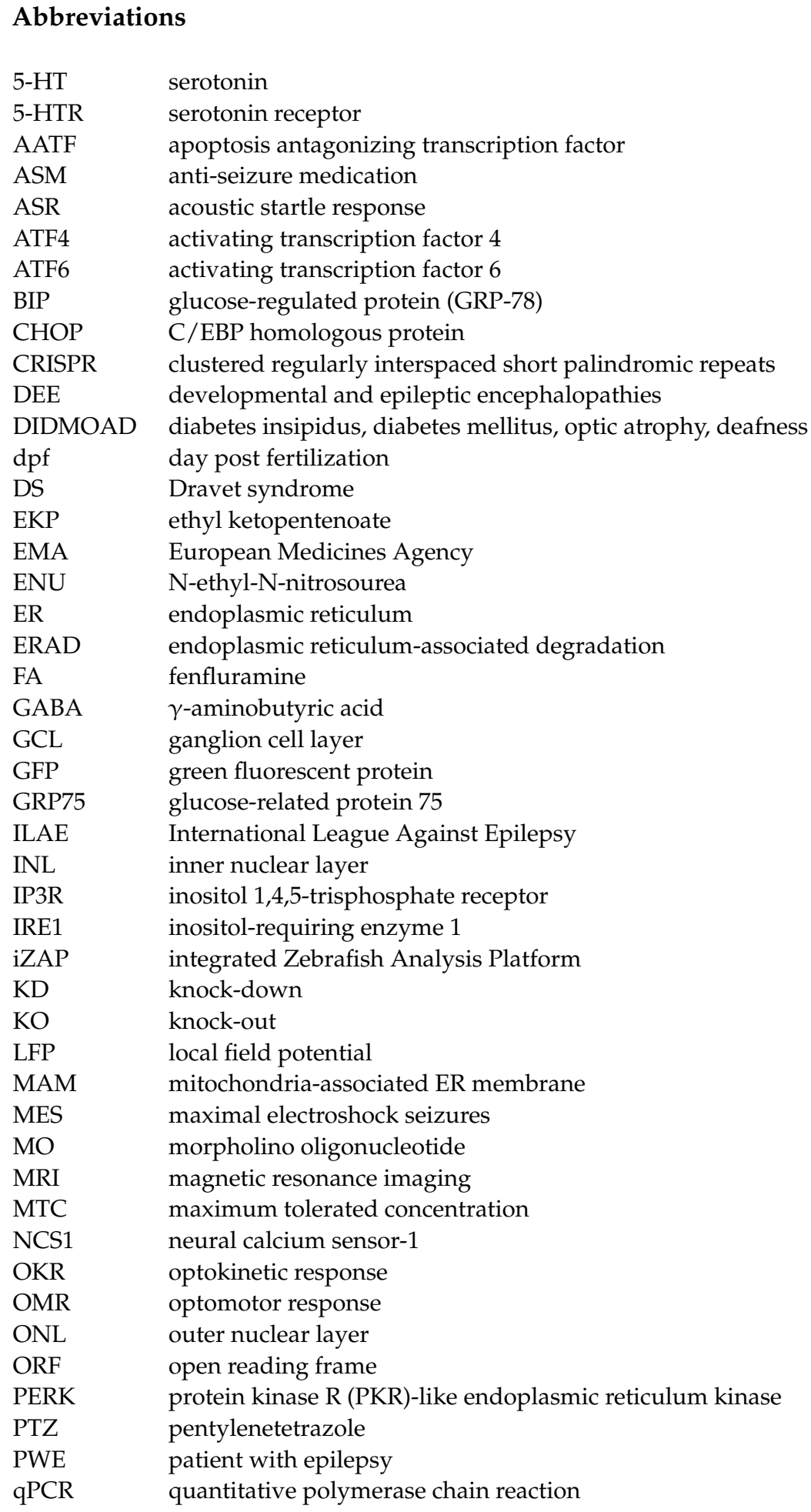




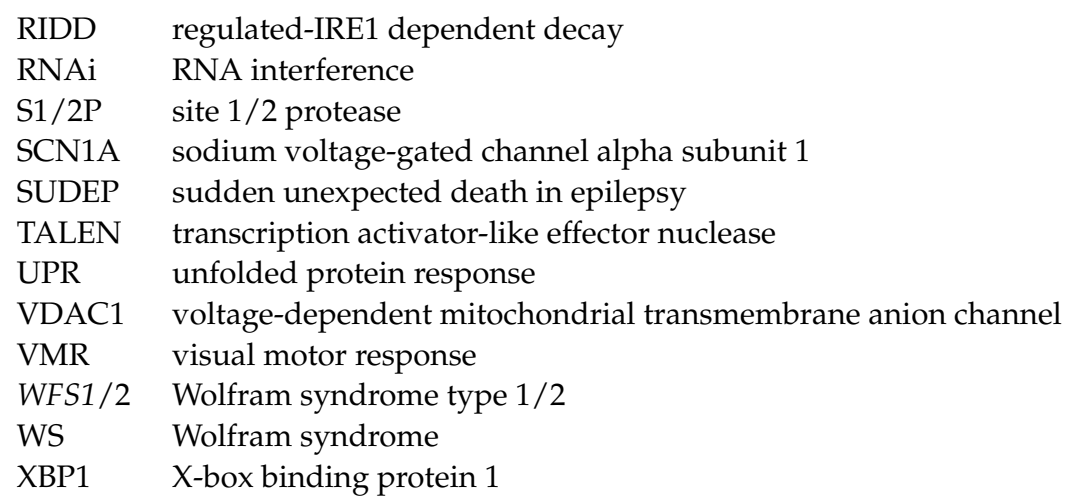

\section{References}

1. Hamilton, F. An Account of the Fishes Found in the River Ganges and Its Branches; Constable \& Robinson Ltd.: Edinburgh, UK, 1822.

2. Spence, R.; Gerlach, G.; Lawrence, C.; Smith, C. The behaviour and ecology of the zebrafish, Danio rerio. Biol. Rev. Camb. Philos. Soc. 2008, 83, 13-34. [CrossRef]

3. Kimmel, C.B.; Ballard, W.W.; Kimmel, S.R.; Ullmann, B.; Schilling, T.F. Stages of embryonic development of the zebrafish. Dev. Dyn. Off. Publ. Am. Assoc. Anat. 1995, 203, 253-310. [CrossRef]

4. Howe, K.; Clark, M.D.; Torroja, C.F.; Torrance, J.; Berthelot, C.; Muffato, M.; Collins, J.E.; Humphray, S.; McLaren, K.; Matthews, L.; et al. The zebrafish reference genome sequence and its relationship to the human genome. Nature 2013, 496 , 498-503. [CrossRef]

5. Lieschke, G.J.; Currie, P.D. Animal models of human disease: Zebrafish swim into view. Nat. Rev. Genet. 2007, 8, 353-367. [CrossRef]

6. Phillips, J.B.; Westerfield, M. Zebrafish models in translational research: Tipping the scales toward advancements in human health. Dis. Models Mech. 2014, 7, 739-743. [CrossRef]

7. White, R.M. Cross-species oncogenomics using zebrafish models of cancer. Curr. Opin. Genet. Dev. 2015, 30, 73-79. [CrossRef] [PubMed]

8. Bai, Q.; Burton, E.A. Zebrafish models of Tauopathy. Biochim. Biophys. Acta 2011, 1812, 353-363. [CrossRef] [PubMed]

9. Bandmann, O.; Burton, E.A. Genetic zebrafish models of neurodegenerative diseases. Neurobiol. Dis. 2010, 40, 58-65. [CrossRef] [PubMed]

10. Das, S.; Rajanikant, G.K. Huntington disease: Can a zebrafish trail leave more than a ripple? Neurosci. Biobehav. Rev. 2014, 45, 258-261. [CrossRef]

11. Laird, A.S.; Mackovski, N.; Rinkwitz, S.; Becker, T.S.; Giacomotto, J. Tissue-specific models of spinal muscular atrophy confirm a critical role of SMN in motor neurons from embryonic to adult stages. Hum. Mol. Genet. 2016, 25, 1728-1738. [CrossRef]

12. Boehmler, W.; Obrecht-Pflumio, S.; Canfield, V.; Thisse, C.; Thisse, B.; Levenson, R. Evolution and expression of D2 and D3 dopamine receptor genes in zebrafish. Dev. Dyn. Off. Publ. Am. Assoc. Anat. 2004, 230, 481-493. [CrossRef] [PubMed]

13. Norton, W.H.J.; Folchert, A.; Bally-Cuif, L. Comparative analysis of serotonin receptor (HTR1A/HTR1B families) and transporter (slc6a4a/b) gene expression in the zebrafish brain. J. Comp. Neurol. 2008, 511, 521-542. [CrossRef]

14. Sanchez-Simon, F.M.; Rodriguez, R.E. Developmental expression and distribution of opioid receptors in zebrafish. Neuroscience 2008, 151, 129-137. [CrossRef]

15. Eliceiri, B.P.; Gonzalez, A.M.; Baird, A. Zebrafish model of the blood-brain barrier: Morphological and permeability studies Methods Mol. Biol. 2011, 686, 371-378. [CrossRef]

16. Jeong, J.-Y.; Kwon, H.-B.; Ahn, J.-C.; Kang, D.; Kwon, S.-H.; Park, J.A.; Kim, K.-W. Functional and developmental analysis of the blood-brain barrier in zebrafish. Brain Res. Bull. 2008, 75, 619-628. [CrossRef] [PubMed]

17. Haffter, P.; Granato, M.; Brand, M.; Mullins, M.C.; Hammerschmidt, M.; Kane, D.A.; Odenthal, J.; van Eeden, F.J.; Jiang, Y.J.; Heisenberg, C.P.; et al. The identification of genes with unique and essential functions in the development of the zebrafish, Danio rerio. Development 1996, 123, 1-36. [CrossRef]

18. Roosen-Runge, E. Observations of the early development of the zebrafish, BrachyDanio rerio. Anat. Rec. 1937, 70, 103.

19. Streisinger, G.; Walker, C.; Dower, N.; Knauber, D.; Singer, F. Production of clones of homozygous diploid zebra fish (BrachyDanio rerio). Nature 1981, 291, 293-296. [CrossRef]

20. Stanton, M.F. Diethylnitrosamine-induced hepatic degeneration and neoplasia in the aquarium fish, Brachydanio rerio. J. Natl. Cancer Inst. 1965, 34, 117-130. [CrossRef]

21. Laale, H.W. Ethanol induced notochord and spinal cord duplications in the embryo of the zebrafish, Brachydanio rerio. J. Exp. Zool. 1971, 177, 51-64. [CrossRef] [PubMed]

22. Bernhardt, R.R.; Tongiorgi, E.; Anzini, P.; Schachner, M. Increased expression of specific recognition molecules by retinal ganglion cells and by optic pathway glia accompanies the successful regeneration of retinal axons in adult zebrafish. J. Comp. Neurol. 1996, 376, 253-264. [CrossRef] 
23. Johnson, S.L.; Weston, J.A. Temperature-sensitive mutations that cause stage-specific defects in Zebrafish fin regeneration. Genetics 1995, 141, 1583-1595. [CrossRef] [PubMed]

24. White, J.A.; Boffa, M.B.; Jones, B.; Petkovich, M. A zebrafish retinoic acid receptor expressed in the regenerating caudal fin. Development 1994, 120, 1861-1872. [CrossRef]

25. Lin, Y.-Y. Muscle diseases in the zebrafish. Neuromuscul. Disord. 2012, 22, 673-684. [CrossRef] [PubMed]

26. Norton, W.H.J. Toward developmental models of psychiatric disorders in zebrafish. Front. Neural Circuits 2013, 7, 79. [CrossRef] [PubMed]

27. Liu, S.; Leach, S.D. Zebrafish Models for Cancer. Annu. Rev. Pathol. Mech. Dis. 2011, 6, 71-93. [CrossRef]

28. Lien, C.-L.; Harrison, M.R.; Tuan, T.-L.; Starnes, V.A. Heart repair and regeneration: Recent insights from zebrafish studies. Wound Repair Regen. 2012, 20, 638-646. [CrossRef]

29. Lohi, O.; Parikka, M.; Rämet, M. The zebrafish as a model for paediatric diseases. Acta Paediatr. 2013, 102, 104-110. [CrossRef]

30. Bilotta, J.; Saszik, S. The zebrafish as a model visual system. Int. J. Dev. Neurosci. 2001, 19, 621-629. [CrossRef]

31. Wang, J.; Yan, Z.; Xing, Y.; Lai, K.; Wang, J.; Yu, D.; Shi, H.; Yin, S. A zebrafish model for hearing loss and regeneration induced by blast wave. J. Bio X Res. 2019, 2, 87-97. [CrossRef]

32. Fuentes, R.; Letelier, J.; Tajer, B.; Valdivia, L.E.; Mullins, M.C. Fishing forward and reverse: Advances in zebrafish phenomics. Mech. Dev. 2018, 154, 296-308. [CrossRef]

33. Simon, M.M.; Moresco, E.M.Y.; Bull, K.R.; Kumar, S.; Mallon, A.-M.; Beutler, B.; Potter, P.K. Current strategies for mutation detection in phenotype-driven screens utilising next generation sequencing. Mamm. Genome 2015, 26, 486-500. [CrossRef]

34. Muto, A.; Orger, M.B.; Wehman, A.M.; Smear, M.C.; Kay, J.N.; Page-McCaw, P.S.; Gahtan, E.; Xiao, T.; Nevin, L.M.; Gosse, N.J.; et al. Forward Genetic Analysis of Visual Behavior in Zebrafish. PLoS Genet. 2005, 1, e66. [CrossRef]

35. Nasevicius, A.; Ekker, S.C. Effective targeted gene 'knockdown' in zebrafish. Nat. Genet. 2000, 26, 216-220. [CrossRef]

36. Summerton, J. Morpholino antisense oligomers: The case for an RNase H-independent structural type. Biochim. Biophys. Acta BBA Gene Struct. Expr. 1999, 1489, 141-158. [CrossRef]

37. Bill, B.R.; Petzold, A.M.; Clark, K.J.; Schimmenti, L.A.; Ekker, S.C. A Primer for Morpholino Use in Zebrafish. Zebrafish 2009, 6, 69-77. [CrossRef]

38. Andrews, O.E.; Cha, D.J.; Wei, C.; Patton, J.G. RNAi-Mediated Gene silencing in Zebrafish Triggered by Convergent Transcription. Sci. Rep. 2015, 4, 5222. [CrossRef] [PubMed]

39. Finckbeiner, S.; Ko, P.-J.; Carrington, B.; Sood, R.; Gross, K.; Dolnick, B.; Sufrin, J.; Liu, P. Transient knockdown and overexpression reveal a developmental role for the zebrafish enosf1b gene. Cell Biosci. 2011, 1, 32. [CrossRef]

40. Rosen, J.N.; Sweeney, M.F.; Mably, J.D. Microinjection of zebrafish embryos to analyze gene function. J. Vis. Exp. 2009, 1115. [CrossRef] [PubMed]

41. Hruscha, A.; Schmid, B. Generation of zebrafish models by CRISPR/Cas9 genome editing. Methods Mol. Biol. 2015, 1254, 341-350. [CrossRef]

42. Huang, P.; Xiao, A.; Zhou, M.; Zhu, Z.; Lin, S.; Zhang, B. Heritable gene targeting in zebrafish using customized TALENs. Nat. Biotechnol. 2011, 29, 699-700. [CrossRef] [PubMed]

43. Hwang, W.Y.; Fu, Y.; Reyon, D.; Maeder, M.L.; Tsai, S.Q.; Sander, J.D.; Peterson, R.T.; Yeh, J.-R.J.; Joung, J.K. Efficient genome editing in zebrafish using a CRISPR-Cas system. Nat. Biotechnol. 2013, 31, 227-229. [CrossRef] [PubMed]

44. Ma, A.C.H.; Chen, Y.; Blackburn, P.R.; Ekker, S.C. TALEN-Mediated Mutagenesis and Genome Editing. Methods Mol. Biol. 2016, 1451, 17-30. [CrossRef]

45. Bahadori, R.; Rinner, O.; Schonthaler, H.B.; Biehlmaier, O.; Makhankov, Y.V.; Rao, P.; Jagadeeswaran, P.; Neuhauss, S.C.F. The Zebrafish fade out mutant: A novel genetic model for Hermansky-Pudlak syndrome. Investig. Ophthalmol. Vis. Sci. 2006, 47, 4523-4531. [CrossRef] [PubMed]

46. Boyadjiev, S.A.; Fromme, J.C.; Ben, J.; Chong, S.S.; Nauta, C.; Hur, D.J.; Zhang, G.; Hamamoto, S.; Schekman, R.; Ravazzola, M.; et al. Cranio-lenticulo-sutural dysplasia is caused by a SEC23A mutation leading to abnormal endoplasmic-reticulum-to-Golgi trafficking. Nat. Genet. 2006, 38, 1192-1197. [CrossRef]

47. Hinkes, B.; Wiggins, R.C.; Gbadegesin, R.; Vlangos, C.N.; Seelow, D.; Nürnberg, G.; Garg, P.; Verma, R.; Chaib, H.; Hoskins, B.E.; et al. Positional cloning uncovers mutations in PLCE1 responsible for a nephrotic syndrome variant that may be reversible. Nat. Genet. 2006, 38, 1397-1405. [CrossRef]

48. Shafizadeh, E.; Paw, B.H.; Foott, H.; Liao, E.C.; Barut, B.A.; Cope, J.J.; Zon, L.I.; Lin, S. Characterization of zebrafish merlot/chablis as non-mammalian vertebrate models for severe congenital anemia due to protein 4.1 deficiency. Dev. Camb. Engl. 2002, 129, 4359-4370. [CrossRef]

49. Winkler, C.; Eggert, C.; Gradl, D.; Meister, G.; Giegerich, M.; Wedlich, D.; Laggerbauer, B.; Fischer, U. Reduced U snRNP assembly causes motor axon degeneration in an animal model for spinal muscular atrophy. Genes Dev. 2005, 19, 2320-2330. [CrossRef]

50. Hoshijima, K.; Jurynec, M.J.; Grunwald, D.J. Precise Editing of the Zebrafish Genome Made Simple and Efficient. Dev. Cell 2016, 36, 654-667. [CrossRef]

51. Schmitt, E.A.; Dowling, J.E. Early eye morphogenesis in the zebrafish, Brachydanio rerio. J. Comp. Neurol. 1994, $344,532-542$. [CrossRef]

52. Maurer, C.M.; Huang, Y.-Y.; Neuhauss, S.C.F. Application of zebrafish oculomotor behavior to model human disorders. Rev. Neurosci. 2011, 22, 5-16. [CrossRef] 
53. Fleisch, V.C.; Neuhauss, S.C.F. Visual behavior in zebrafish. Zebrafish 2006, 3, 191-201. [CrossRef]

54. Schmitt, E.A.; Dowling, J.E. Early retinal development in the zebrafish, Danio rerio: Light and electron microscopic analyses. J. Comp. Neurol. 1999, 404, 515-536. [CrossRef]

55. Chinen, A.; Hamaoka, T.; Yamada, Y.; Kawamura, S. Gene Duplication and Spectral Diversification of Cone Visual Pigments of Zebrafish. Genetics 2003, 163, 663-675. [CrossRef] [PubMed]

56. Vihtelic, T.S.; Doro, C.J.; Hyde, D.R. Cloning and characterization of six zebrafish photoreceptor opsin cDNAs and immunolocalization of their corresponding proteins. Vis. Neurosci. 1999, 16, 571-585. [CrossRef]

57. Crouzier, L.; Diez, C.; Richard, E.M.; Cubedo, N.; Barbereau, C.; Rossel, M.; Delaunay, T.; Maurice, T.; Delprat, B. Loss of Pde6a Induces Rod Outer Segment Shrinkage and Visual Alterations in pde6aQ70X Mutant Zebrafish, a Relevant Model of Retinal Dystrophy. Front. Cell Dev. Biol. 2021, 9, 675517. [CrossRef] [PubMed]

58. Venkatraman, P.; Mills-Henry, I.; Padmanabhan, K.R.; Pascuzzi, P.; Hassan, M.; Zhang, J.; Zhang, X.; Ma, P.; Pang, C.P.; Dowling, J.E.; et al. Rods Contribute to Visual Behavior in Larval Zebrafish. Investig. Opthalmol. Vis. Sci. 2020, 61, 11. [CrossRef] [PubMed]

59. Burrill, J.D.; Easter, S.S. Development of the retinofugal projections in the embryonic and larval zebrafish (BrachyDanio rerio). J. Comp. Neurol. 1994, 346, 583-600. [CrossRef]

60. Easter, S.S.; Nicola, G.N. The development of eye movements in the zebrafish (Danio rerio). Dev. Psychobiol. 1997, 31, 267-276. [CrossRef]

61. Biehlmaier, O.; Neuhauss, S.C.F.; Kohler, K. Double cone dystrophy and RPE degeneration in the retina of the zebrafish gnn mutant. Investig. Ophthalmol. Vis. Sci. 2003, 44, 1287-1298. [CrossRef]

62. Li, X.-Q.; Cai, H.-C.; Zhou, S.-Y.; Yang, J.-H.; Xi, Y.-B.; Gao, X.-B.; Zhao, W.-J.; Li, P.; Zhao, G.-Y.; Tong, Y.; et al. A novel mutation impairing the tertiary structure and stability of $\gamma \mathrm{C}$-crystallin (CRYGC) leads to cataract formation in humans and zebrafish lens. Hum. Mutat. 2012, 33, 391-401. [CrossRef]

63. Neuhauss, S.C.F.; Biehlmaier, O.; Seeliger, M.W.; Das, T.; Kohler, K.; Harris, W.A.; Baier, H. Genetic Disorders of Vision Revealed by a Behavioral Screen of 400 Essential Loci in Zebrafish. J. Neurosci. 1999, 19, 8603-8615. [CrossRef] [PubMed]

64. Orger, M.B.; Baier, H. Channeling of red and green cone inputs to the zebrafish optomotor response. Vis. Neurosci. 2005, 22, 275-281. [CrossRef]

65. Richards, F.M.; Alderton, W.K.; Kimber, G.M.; Liu, Z.; Strang, I.; Redfern, W.S.; Valentin, J.-P.; Winter, M.J.; Hutchinson, T.H. Validation of the use of zebrafish larvae in visual safety assessment. J. Pharmacol. Toxicol. Methods 2008, 58, 50-58. [CrossRef]

66. Brockerhoff, S.E.; Hurley, J.B.; Janssen-Bienhold, U.; Neuhauss, S.C.; Driever, W.; Dowling, J.E. A behavioral screen for isolating zebrafish mutants with visual system defects. Proc. Natl. Acad. Sci. USA 1995, 92, 10545-10549. [CrossRef]

67. Huber-Reggi, S.P.; Mueller, K.P.; Neuhauss, S.C.F. Analysis of Optokinetic Response in Zebrafish by Computer-Based Eye Tracking. In Retinal Degeneration: Methods and Protocols; Weber, B.H.F., Langmann, T., Eds.; Humana Press: Totowa, NJ, USA, 2013; pp. 139-160. ISBN 978-1-62703-080-9.

68. Deeti, S.; O'Farrell, S.; Kennedy, B.N. Early safety assessment of human oculotoxic drugs using the zebrafish visualmotor response. J. Pharmacol. Toxicol. Methods 2014, 69, 1-8. [CrossRef] [PubMed]

69. Emran, F.; Rihel, J.; Dowling, J.E. A behavioral assay to measure responsiveness of zebrafish to changes in light intensities. J. Vis. Exp. 2008, 20, 103. [CrossRef]

70. Zhang, L.; Xiang, L.; Liu, Y.; Venkatraman, P.; Chong, L.; Cho, J.; Bonilla, S.; Jin, Z.-B.; Pang, C.P.; Ko, K.M.; et al. A NaturallyDerived Compound Schisandrin B Enhanced Light Sensation in the pde6c Zebrafish Model of Retinal Degeneration. PLoS ONE 2016, 11, e0149663. [CrossRef]

71. Ernest, S.; Rauch, G.J.; Haffter, P.; Geisler, R.; Petit, C.; Nicolson, T. Mariner is defective in myosin VIIA: A zebrafish model for human hereditary deafness. Hum. Mol. Genet. 2000, 9, 2189-2196. [CrossRef]

72. Phillips, J.B.; Blanco-Sanchez, B.; Lentz, J.J.; Tallafuss, A.; Khanobdee, K.; Sampath, S.; Jacobs, Z.G.; Han, P.F.; Mishra, M.; Titus, T.A.; et al. Harmonin (Ush1c) is required in zebrafish Müller glial cells for photoreceptor synaptic development and function. Dis. Models Mech. 2011, 4, 786-800. [CrossRef] [PubMed]

73. Söllner, C.; Rauch, G.-J.; Siemens, J.; Geisler, R.; Schuster, S.C.; Müller, U.; Nicolson, T. Tübingen 2000 Screen Consortium Mutations in cadherin 23 affect tip links in zebrafish sensory hair cells. Nature 2004, 428, 955-959. [CrossRef] [PubMed]

74. Yariz, K.O.; Duman, D.; Zazo Seco, C.; Dallman, J.; Huang, M.; Peters, T.A.; Sirmaci, A.; Lu, N.; Schraders, M.; Skromne, I.; et al. Mutations in OTOGL, encoding the inner ear protein otogelin-like, cause moderate sensorineural hearing loss. Am. J. Hum. Genet. 2012, 91, 872-882. [CrossRef]

75. Chiu, L.L.; Cunningham, L.L.; Raible, D.W.; Rubel, E.W.; Ou, H.C. Using the zebrafish lateral line to screen for ototoxicity. J. Assoc. Res. Otolaryngol. JARO 2008, 9, 178-190. [CrossRef]

76. Coffin, A.B.; Ou, H.; Owens, K.N.; Santos, F.; Simon, J.A.; Rubel, E.W.; Raible, D.W. Chemical screening for hair cell loss and protection in the zebrafish lateral line. Zebrafish 2010, 7, 3-11. [CrossRef]

77. He, Y.; Bao, B.; Li, H. Using zebrafish as a model to study the role of epigenetics in hearing loss. Expert Opin. Drug Discov. 2017, 12, 967-975. [CrossRef]

78. Owens, K.N.; Coffin, A.B.; Hong, L.S.; Bennett, K.O.; Rubel, E.W.; Raible, D.W. Response of mechanosensory hair cells of the zebrafish lateral line to aminoglycosides reveals distinct cell death pathways. Hear. Res. 2009, 253, 32-41. [CrossRef] 
79. Wang, C.; Zhong, Z.; Sun, P.; Zhong, H.; Li, H.; Chen, F. Evaluation of the Hair Cell Regeneration in Zebrafish Larvae by Measuring and Quantifying the Startle Responses. Neural Plast. 2017, 2017, 8283075. [CrossRef]

80. Baxendale, S.; Whitfield, T.T. Methods to study the development, anatomy, and function of the zebrafish inner ear across the life course. Methods Cell Biol. 2016, 134, 165-209. [PubMed]

81. Whitfield, T.T.; Hammond, K.L. Axial patterning in the developing vertebrate inner ear. Int. J. Dev. Biol. 2007, 51, 507-520. [CrossRef] [PubMed]

82. Bever, M.M.; Fekete, D.M. Atlas of the developing inner ear in zebrafish. Dev. Dyn. 2002, 223, 536-543. [CrossRef] [PubMed]

83. Nicolson, T. The genetics of hearing and balance in zebrafish. Annu. Rev. Genet. 2005, 39, 9-22. [CrossRef]

84. Riley, B.B.; Moorman, S.J. Development of utricular otoliths, but not saccular otoliths, is necessary for vestibular function and survival in zebrafish. J. Neurobiol. 2000, 43, 329-337. [CrossRef]

85. Bang, P.I.; Sewell, W.F.; Malicki, J.J. Morphology and cell type heterogeneities of the inner ear epithelia in adult and juvenile zebrafish (Danio rerio). J. Comp. Neurol. 2001, 438, 173-190. [CrossRef]

86. Hudspeth, A.J. Hair-bundle mechanics and a model for mechanoelectrical transduction by hair cells. Soc. Gen. Physiol. Ser. 1992, 47, 357-370. [PubMed]

87. Dijkgraaf, S. The functioning and significance of the lateral-line organs. Biol. Rev. Camb. Philos. Soc. 1963, 38, 51-105. [CrossRef]

88. Kanter, M.J.; Coombs, S. Rheotaxis and prey detection in uniform currents by Lake Michigan mottled sculpin (Cottus bairdi). J. Exp. Biol. 2003, 206, 59-70. [CrossRef]

89. Montgomery, J.C.; Baker, C.F.; Carton, A.G. The lateral line can mediate rheotaxis in fish. Nature 1997, 389, 960-963. [CrossRef]

90. Pitcher, T.J.; Partridge, B.L.; Wardle, C.S. A blind fish can school. Science 1976, 194, 963-965. [CrossRef] [PubMed]

91. Conley, R.A.; Coombs, S. Dipole source localization by mottled sculpin. III. Orientation after site-specific, unilateral denervation of the lateral line system. J. Comp. Physiol. A 1998, 183, 335-344. [CrossRef]

92. Coombs, S.; Braun, C.B.; Donovan, B. The orienting response of Lake Michigan mottled sculpin is mediated by canal neuromasts. J. Exp. Biol. 2001, 204, 337-348. [CrossRef]

93. Montgomery, J.C.; Coombs, S. Peripheral encoding of moving sources by the lateral line system of a sit-and-wait predator. J. Exp. Biol. 1998, 201, 91-102. [CrossRef]

94. Blaxter, J.H.S.; Fuiman, L.A. Function of the Free Neuromasts of Marine Teleost Larvae. In The Mechanosensory Lateral Line; Coombs, S., Görner, P., Münz, H., Eds.; Springer: New York, NY, USA, 1989; pp. 481-499.

95. Metcalfe, W.K.; Kimmel, C.B.; Schabtach, E. Anatomy of the posterior lateral line system in young larvae of the zebrafish. J. Comp. Neurol. 1985, 233, 377-389. [CrossRef]

96. McHenry, M.J.; van Netten, S.M. The flexural stiffness of superficial neuromasts in the zebrafish (Danio rerio) lateral line. J. Exp. Biol. 2007, 210, 4244-4253. [CrossRef] [PubMed]

97. Ghysen, A.; Dambly-Chaudière, C. Development of the zebrafish lateral line. Curr. Opin. Neurobiol. 2004, 14, 67-73. [CrossRef]

98. McDermott, B.M.; Asai, Y.; Baucom, J.M.; Jani, S.D.; Castellanos, Y.; Gomez, G.; McClintock, J.M.; Hudspeth, A.J. Transgenic Labeling of Hair Cells in the Zebrafish Acousticolateralis System. Gene Expr. Patterns GEP 2010, 10, 113-118. [CrossRef] [PubMed]

99. Williams, J.A.; Holder, N. Cell turnover in neuromasts of zebrafish larvae. Hear. Res. 2000, 143, 171-181. [CrossRef]

100. Harris, J.A.; Cheng, A.G.; Cunningham, L.L.; MacDonald, G.; Raible, D.W.; Rubel, E.W. Neomycin-Induced Hair Cell Death and Rapid Regeneration in the Lateral Line of Zebrafish (Danio rerio). JARO J. Assoc. Res. Otolaryngol. 2003, 4, 219-234. [CrossRef]

101. Ou, H.C.; Raible, D.W.; Rubel, E.W. Cisplatin-induced hair cell loss in zebrafish (Danio rerio) lateral line. Hear. Res. 2007, 233, 46-53. [CrossRef]

102. Ton, C.; Parng, C. The use of zebrafish for assessing ototoxic and otoprotective agents. Hear. Res. 2005, 208, 79-88. [CrossRef]

103. Domarecka, E.; Skarzynska, M.; Szczepek, A.J.; Hatzopoulos, S. Use of zebrafish larvae lateral line to study protection against cisplatin-induced ototoxicity: A scoping review. Int. J. Immunopathol. Pharmacol. 2020, 34, 205873842095955. [CrossRef]

104. Vlasits, A.L.; Simon, J.A.; Raible, D.W.; Rubel, E.W.; Owens, K.N. Screen of FDA-approved drug library reveals compounds that protect hair cells from aminoglycosides and cisplatin. Hear. Res. 2012, 294, 153-165. [CrossRef]

105. Vanwalleghem, G.; Heap, L.A.; Scott, E.K. A profile of auditory-responsive neurons in the larval zebrafish brain. J. Comp. Neurol. 2017, 525, 3031-3043. [CrossRef] [PubMed]

106. Kimmel, C.B.; Patterson, J.; Kimmel, R.O. The development and behavioral characteristics of the startle response in the zebra fish. Dev. Psychobiol. 1974, 7, 47-60. [CrossRef]

107. Zeddies, D.G.; Fay, R.R. Development of the acoustically evoked behavioral response in zebrafish to pure tones. J. Exp. Biol. 2005, 208, 1363-1372. [CrossRef]

108. Bhandiwad, A.A.; Sisneros, J.A. Revisiting Psychoacoustic Methods for the Assessment of Fish Hearing. Adv. Exp. Med. Biol. 2016, 877, 157-184. [CrossRef]

109. Liu, X.; Lin, J.; Zhang, Y.; Guo, N.; Li, Q. Sound shock response in larval zebrafish: A convenient and high-throughput assessment of auditory function. Neurotoxicol. Teratol. 2018, 66, 1-7. [CrossRef] [PubMed]

110. Singh, A.; Trevick, S. The Epidemiology of Global Epilepsy. Neurol. Clin. 2016, 34, 837-847. [CrossRef] [PubMed]

111. Scheffer, I.E.; Berkovic, S.; Capovilla, G.; Connolly, M.B.; French, J.; Guilhoto, L.; Hirsch, E.; Jain, S.; Mathern, G.W.; Moshé, S.L.; et al. ILAE classification of the epilepsies: Position paper of the ILAE Commission for Classification and Terminology. Epilepsia 2017, 58, 512-521. [CrossRef] 
112. Yaksi, E.; Jamali, A.; Diaz Verdugo, C.; Jurisch-Yaksi, N. Past, present and future of zebrafish in epilepsy research. FEBS J. 2021. [CrossRef]

113. Burrows, D.R.W.; Samarut, É.; Liu, J.; Baraban, S.C.; Richardson, M.P.; Meyer, M.P.; Rosch, R.E. Imaging epilepsy in larval zebrafish. Eur. J. Paediatr. Neurol. 2020, 24, 70-80. [CrossRef]

114. Cunliffe, V.T. Building a zebrafish toolkit for investigating the pathobiology of epilepsy and identifying new treatments for epileptic seizures. J. Neurosci. Methods 2016, 260, 91-95. [CrossRef]

115. Cunliffe, V.T.; Baines, R.A.; Giachello, C.N.G.; Lin, W.-H.; Morgan, A.; Reuber, M.; Russell, C.; Walker, M.C.; Williams, R.S.B. Epilepsy research methods update: Understanding the causes of epileptic seizures and identifying new treatments using non-mammalian model organisms. Seizure 2015, 24, 44-51. [CrossRef] [PubMed]

116. Ibhazehiebo, K.; Rho, J.M.; Kurrasch, D.M. Metabolism-based drug discovery in zebrafish: An emerging strategy to uncover new anti-seizure therapies. Neuropharmacology 2020, 167, 107988. [CrossRef]

117. Tiraboschi, E.; Martina, S.; Ent, W.; Grzyb, K.; Gawel, K.; Cordero-Maldonado, M.L.; Poovathingal, S.K.; Heintz, S.; Satheesh, S.V.; Brattespe, J.; et al. New insights into the early mechanisms of epileptogenesis in a zebrafish model of Dravet syndrome. Epilepsia 2020, 61, 549-560. [CrossRef]

118. Stafstrom, C.E.; Kossoff, E.H. Epileptic Encephalopathy in Infants and Children. Epilepsy Curr. 2016, 16, 273-279. [CrossRef]

119. Ellis, C.A.; Petrovski, S.; Berkovic, S.F. Epilepsy genetics: Clinical impacts and biological insights. Lancet Neurol. 2020, 19, 93-100. [CrossRef]

120. Baraban, S.C. A zebrafish-centric approach to antiepileptic drug development. Dis. Models Mech. 2021, 14, dmm049080. [CrossRef] [PubMed]

121. Copmans, D.; Siekierska, A.; de Witte, P.A.M. Chapter 26 - Zebrafish Models of Epilepsy and Epileptic Seizures. In Models of Seizures and Epilepsy, 2nd ed.; Academic Press: New York, NY, USA, 2017; pp. 369-384.

122. Baraban, S.C.; Taylor, M.R.; Castro, P.A.; Baier, H. Pentylenetetrazole induced changes in zebrafish behavior, neural activity and c-fos expression. Neuroscience 2005, 131, 759-768. [CrossRef]

123. Gawel, K.; Langlois, M.; Martins, T.; van der Ent, W.; Tiraboschi, E.; Jacmin, M.; Crawford, A.D.; Esguerra, C.V. Seizing the moment: Zebrafish epilepsy models. Neurosci. Biobehav. Rev. 2020, 116, 1-20. [CrossRef]

124. Kumari, S.; Sharma, P.; Mazumder, A.G.; Rana, A.K.; Sharma, S.; Singh, D. Development and validation of chemical kindling in adult zebrafish: A simple and improved chronic model for screening of antiepileptic agents. J. Neurosci. Methods 2020, 346, 108916. [CrossRef] [PubMed]

125. Pieróg, M.; Socała, K.; Doboszewska, U.; Wyska, E.; Guz, L.; Szopa, A.; Serefko, A.; Poleszak, E.; Wlaź, P. Effects of classic antiseizure drugs on seizure activity and anxiety-like behavior in adult zebrafish. Toxicol. Appl. Pharmacol. 2021, 415, 115429. [CrossRef]

126. Sourbron, J.; Partoens, M.; Scheldeman, C.; Zhang, Y.; Lagae, L.; Witte, P. Drug repurposing for Dravet syndrome in scn1Lab ${ }^{-/-}$ mutant zebrafish. Epilepsia 2019, 60, e8-e13. [CrossRef] [PubMed]

127. Zhang, Y.; Vanmeert, M.; Siekierska, A.; Ny, A.; John, J.; Callewaert, G.; Lescrinier, E.; Dehaen, W.; de Witte, P.A.M.; Kaminski, R.M. Inhibition of glutamate decarboxylase (GAD) by ethyl ketopentenoate (EKP) induces treatment-resistant epileptic seizures in zebrafish. Sci. Rep. 2017, 7, 7195. [CrossRef] [PubMed]

128. Duy, P.Q.; Berberoglu, M.A.; Beattie, C.E.; Hall, C.W. Cellular responses to recurrent pentylenetetrazole-induced seizures in the adult zebrafish brain. Neuroscience 2017, 349, 118-127. [CrossRef]

129. Cho, S.-J.; Park, E.; Telliyan, T.; Baker, A.; Reid, A.Y. Zebrafish model of posttraumatic epilepsy. Epilepsia 2020, 61, 1774-1785. [CrossRef]

130. Afrikanova, T.; Serruys, A.-S.K.; Buenafe, O.E.M.; Clinckers, R.; Smolders, I.; de Witte, P.A.M.; Crawford, A.D.; Esguerra, C.V. Validation of the zebrafish pentylenetetrazol seizure model: Locomotor versus electrographic responses to antiepileptic drugs. PLoS ONE 2013, 8, e54166. [CrossRef]

131. Sourbron, J.; Schneider, H.; Kecskés, A.; Liu, Y.; Buening, E.M.; Lagae, L.; Smolders, I.; de Witte, P. Serotonergic Modulation as Effective Treatment for Dravet Syndrome in a Zebrafish Mutant Model. ACS Chem. Neurosci. 2016, 7, 588-598. [CrossRef]

132. Griffin, A.; Hamling, K.R.; Knupp, K.; Hong, S.; Lee, L.P.; Baraban, S.C. Clemizole and modulators of serotonin signalling suppress seizures in Dravet syndrome. Brain 2017, 140, 669-683. [CrossRef] [PubMed]

133. Buenafe, O.E.; Orellana-Paucar, A.; Maes, J.; Huang, H.; Ying, X.; De Borggraeve, W.; Crawford, A.D.; Luyten, W.; Esguerra, C.V.; de Witte, P. Tanshinone IIA Exhibits Anticonvulsant Activity in Zebrafish and Mouse Seizure Models. ACS Chem. Neurosci. 2013, 4, 1479-1487. [CrossRef]

134. Orellana-Paucar, A.M.; Serruys, A.-S.K.; Afrikanova, T.; Maes, J.; De Borggraeve, W.; Alen, J.; León-Tamariz, F.; Wilches-Arizábala, I.M.; Crawford, A.D.; de Witte, P.A.M.; et al. Anticonvulsant activity of bisabolene sesquiterpenoids of Curcuma longa in zebrafish and mouse seizure models. Epilepsy Behav. 2012, 24, 14-22. [CrossRef] [PubMed]

135. Sourbron, J.; Smolders, I.; de Witte, P.; Lagae, L. Pharmacological Analysis of the Anti-epileptic Mechanisms of Fenfluramine in scn1a Mutant Zebrafish. Front. Pharmacol. 2017, 8, 191. [CrossRef]

136. Liu, M.; Copmans, D.; Lu, J.-G.; Yang, M.-R.; Sourbron, J.; Ny, A.; Jiang, Z.-H.; de Witte, P.A.M.; Luyten, W. Bioassay-guided isolation of anti-seizure principles from Semen Pharbitidis using a zebrafish pentylenetetrazol seizure model. J. Ethnopharmacol. 2019, 232, 130-134. [CrossRef]

137. Monach, P.A. Repeating tests: Different roles in research studies and clinical medicine. Biomark. Med. 2012, 6, 691-703. [CrossRef] 
138. Baraban, S.C.; Dinday, M.T.; Hortopan, G.A. Drug screening in Scn1a zebrafish mutant identifies clemizole as a potential Dravet syndrome treatment. Nat. Commun. 2013, 4, 2410. [CrossRef]

139. Baxendale, S.; Holdsworth, C.J.; Meza Santoscoy, P.L.; Harrison, M.R.M.; Fox, J.; Parkin, C.A.; Ingham, P.W.; Cunliffe, V.T. Identification of compounds with anti-convulsant properties in a zebrafish model of epileptic seizures. Dis. Models Mech. 2012, 5, 773-784. [CrossRef] [PubMed]

140. Griffin, A.L.; Jaishankar, P.; Grandjean, J.-M.; Olson, S.H.; Renslo, A.R.; Baraban, S.C. Zebrafish studies identify serotonin receptors mediating antiepileptic activity in Dravet syndrome. Brain Commun. 2019, 1, fcz008. [CrossRef]

141. Diaz Verdugo, C.; Myren-Svelstad, S.; Aydin, E.; Van Hoeymissen, E.; Deneubourg, C.; Vanderhaeghe, S.; Vancraeynest, J.; Pelgrims, R.; Cosacak, M.I.; Muto, A.; et al. Glia-neuron interactions underlie state transitions to generalized seizures. Nat. Commun. 2019, 10, 3830. [CrossRef]

142. Hong, S.; Lee, P.; Baraban, S.C.; Lee, L.P. A Novel Long-term, Multi-Channel and Non-invasive Electrophysiology Platform for Zebrafish. Sci. Rep. 2016, 6, 28248. [CrossRef]

143. Meyer, M.; Dhamne, S.C.; LaCoursiere, C.M.; Tambunan, D.; Poduri, A.; Rotenberg, A. Microarray Noninvasive Neuronal Seizure Recordings from Intact Larval Zebrafish. PLoS ONE 2016, 11, e0156498. [CrossRef]

144. Khateb, M.; Bosak, N.; Herskovitz, M. The Effect of Anti-seizure Medications on the Propagation of Epileptic Activity: A Review. Front. Neurol. 2021, 12, 674182. [CrossRef]

145. Berio, A.; Piazzi, A. Activity of drugs and components of natural origin in the severe myoclonic epilepsy of infancy (Dravet syndrome). Cent. Nerv. Syst. Agents Med. Chem. 2015, 15, 95-98. [CrossRef]

146. Naumann, E.A.; Kampff, A.R.; Prober, D.A.; Schier, A.F.; Engert, F. Monitoring neural activity with bioluminescence during natural behavior. Nat. Neurosci. 2010, 13, 513-520. [CrossRef] [PubMed]

147. Wolfram, D.; Wagener, H.P. Diabetes mellitus and simple optic atrophy among siblings: Report of four cases. Mayo Clin. Proc. 1938, 13, 715-718.

148. Barrett, T.G.; Bundey, S.E.; Macleod, A.F. Neurodegeneration and diabetes: UK nationwide study of Wolfram (DIDMOAD) syndrome. Lancet Lond. Engl. 1995, 346, 1458-1463. [CrossRef]

149. Tekgül, S.; Oge, O.; Simşek, E.; Yordam, N.; Kendi, S. Urological manifestations of the Wolfram syndrome: Observations in 14 patients. J. Urol. 1999, 161, 616-617. [CrossRef]

150. Aldenhövel, H.G.; Gallenkamp, U.; Sulemana, C.A. Juvenile onset diabetes mellitus, central diabetes insipidus and optic atrophy (Wolfram syndrome)-Neurological findings and prognostic implications. Neuropediatrics 1991, 22, 103-106. [CrossRef]

151. Swift, R.G.; Sadler, D.B.; Swift, M. Psychiatric findings in Wolfram syndrome homozygotes. Lancet Lond. Engl. 1990, 336, 667-669. [CrossRef]

152. Kinsley, B.T.; Swift, M.; Dumont, R.H.; Swift, R.G. Morbidity and mortality in the Wolfram syndrome. Diabetes Care 1995, 18, 1566-1570. [CrossRef]

153. Kumar, S. Wolfram syndrome: Important implications for pediatricians and pediatric endocrinologists. Pediatr. Diabetes 2010, 11, 28-37. [CrossRef]

154. Matsunaga, K.; Tanabe, K.; Inoue, H.; Okuya, S.; Ohta, Y.; Akiyama, M.; Taguchi, A.; Kora, Y.; Okayama, N.; Yamada, Y.; et al. Wolfram syndrome in the Japanese population; molecular analysis of WFS1 gene and characterization of clinical features. PLoS ONE 2014, 9, e106906. [CrossRef]

155. Fraser, F.C.; Gunn, T. Diabetes mellitus, diabetes insipidus, and optic atrophy. An autosomal recessive syndrome? J. Med. Genet. 1977, 14, 190-193. [CrossRef]

156. Medlej, R.; Wasson, J.; Baz, P.; Azar, S.; Salti, I.; Loiselet, J.; Permutt, A.; Halaby, G. Diabetes mellitus and optic atrophy: A study of Wolfram syndrome in the Lebanese population. J. Clin. Endocrinol. Metab. 2004, 89, 1656-1661. [CrossRef]

157. Amr, S.; Heisey, C.; Zhang, M.; Xia, X.-J.; Shows, K.H.; Ajlouni, K.; Pandya, A.; Satin, L.S.; El-Shanti, H.; Shiang, R. A homozygous mutation in a novel zinc-finger protein, ERIS, is responsible for Wolfram syndrome 2. Am. J. Hum. Genet. 2007, 81, 673-683. [CrossRef]

158. Inoue, H.; Tanizawa, Y.; Wasson, J.; Behn, P.; Kalidas, K.; Bernal-Mizrachi, E.; Mueckler, M.; Marshall, H.; Donis-Keller, H.; Crock, P.; et al. A gene encoding a transmembrane protein is mutated in patients with diabetes mellitus and optic atrophy (Wolfram syndrome). Nat. Genet. 1998, 20, 143-148. [CrossRef]

159. Strom, T.M.; Hörtnagel, K.; Hofmann, S.; Gekeler, F.; Scharfe, C.; Rabl, W.; Gerbitz, K.D.; Meitinger, T. Diabetes insipidus, diabetes mellitus, optic atrophy and deafness (DIDMOAD) caused by mutations in a novel gene (wolframin) coding for a predicted transmembrane protein. Hum. Mol. Genet. 1998, 7, 2021-2028. [CrossRef] [PubMed]

160. Hardy, C.; Khanim, F.; Torres, R.; Scott-Brown, M.; Seller, A.; Poulton, J.; Collier, D.; Kirk, J.; Polymeropoulos, M.; Latif, F.; et al. Clinical and molecular genetic analysis of 19 Wolfram syndrome kindreds demonstrating a wide spectrum of mutations in WFS1. Am. J. Hum. Genet. 1999, 65, 1279-1290. [CrossRef]

161. Takeda, K.; Inoue, H.; Tanizawa, Y.; Matsuzaki, Y.; Oba, J.; Watanabe, Y.; Shinoda, K.; Oka, Y. WFS1 (Wolfram syndrome 1) gene product: Predominant subcellular localization to endoplasmic reticulum in cultured cells and neuronal expression in rat brain. Hum. Mol. Genet. 2001, 10, 477-484. [CrossRef]

162. Hofmann, S.; Philbrook, C.; Gerbitz, K.-D.; Bauer, M.F. Wolfram syndrome: Structural and functional analyses of mutant and wild-type wolframin, the WFS1 gene product. Hum. Mol. Genet. 2003, 12, 2003-2012. [CrossRef] 
163. Harding, H.P.; Calfon, M.; Urano, F.; Novoa, I.; Ron, D. Transcriptional and translational control in the Mammalian unfolded protein response. Annu. Rev. Cell Dev. Biol. 2002, 18, 575-599. [CrossRef] [PubMed]

164. Patil, C.; Walter, P. Intracellular signaling from the endoplasmic reticulum to the nucleus: The unfolded protein response in yeast and mammals. Curr. Opin. Cell Biol. 2001, 13, 349-355. [CrossRef]

165. Fonseca, S.G.; Fukuma, M.; Lipson, K.L.; Nguyen, L.X.; Allen, J.R.; Oka, Y.; Urano, F. WFS1 is a novel component of the unfolded protein response and maintains homeostasis of the endoplasmic reticulum in pancreatic beta-cells. J. Biol. Chem. 2005, 280, 39609-39615. [CrossRef]

166. Osman, A.A.; Saito, M.; Makepeace, C.; Permutt, M.A.; Schlesinger, P.; Mueckler, M. Wolframin expression induces novel ion channel activity in endoplasmic reticulum membranes and increases intracellular calcium. J. Biol. Chem. 2003, 278, 52755-52762 [CrossRef]

167. Lu, S.; Kanekura, K.; Hara, T.; Mahadevan, J.; Spears, L.D.; Oslowski, C.M.; Martinez, R.; Yamazaki-Inoue, M.; Toyoda, M.; Neilson, A.; et al. A calcium-dependent protease as a potential therapeutic target for Wolfram syndrome. Proc. Natl. Acad. Sci. USA 2014, 111, E5292-E5301. [CrossRef]

168. Takei, D.; Ishihara, H.; Yamaguchi, S.; Yamada, T.; Tamura, A.; Katagiri, H.; Maruyama, Y.; Oka, Y. WFS1 protein modulates the free $\mathrm{Ca}^{2+}$ concentration in the endoplasmic reticulum. FEBS Lett. 2006, 580, 5635-5640. [CrossRef]

169. Luuk, H.; Koks, S.; Plaas, M.; Hannibal, J.; Rehfeld, J.F.; Vasar, E. Distribution of WFS1 protein in the central nervous system of the mouse and its relation to clinical symptoms of the Wolfram syndrome. J. Comp. Neurol. 2008, 509, 642-660. [CrossRef]

170. Kakiuchi, C.; Ishiwata, M.; Hayashi, A.; Kato, T. XBP1 induces WFS1 through an endoplasmic reticulum stress response element-like motif in SH-SY5Y cells. J. Neurochem. 2006, 97, 545-555. [CrossRef]

171. Shang, L.; Hua, H.; Foo, K.; Martinez, H.; Watanabe, K.; Zimmer, M.; Kahler, D.J.; Freeby, M.; Chung, W.; LeDuc, C.; et al. $\beta$-Cell Dysfunction Due to Increased ER Stress in a Stem Cell Model of Wolfram Syndrome. Diabetes 2014, 63, 923-933. [CrossRef]

172. Ueda, K.; Kawano, J.; Takeda, K.; Yujiri, T.; Tanabe, K.; Anno, T.; Akiyama, M.; Nozaki, J.; Yoshinaga, T.; Koizumi, A.; et al. Endoplasmic reticulum stress induces WFS1 gene expression in pancreatic beta-cells via transcriptional activation. Eur. J. Endocrinol. 2005, 153, 167-176. [CrossRef] [PubMed]

173. Yamada, T.; Ishihara, H.; Tamura, A.; Takahashi, R.; Yamaguchi, S.; Takei, D.; Tokita, A.; Satake, C.; Tashiro, F.; Katagiri, H.; et al. WFS1-deficiency increases endoplasmic reticulum stress, impairs cell cycle progression and triggers the apoptotic pathway specifically in pancreatic beta-cells. Hum. Mol. Genet. 2006, 15, 1600-1609. [CrossRef] [PubMed]

174. Kato, T.; Ishiwata, M.; Yamada, K.; Kasahara, T.; Kakiuchi, C.; Iwamoto, K.; Kawamura, K.; Ishihara, H.; Oka, Y. Behavioral and gene expression analyses of WFS1 knockout mice as a possible animal model of mood disorder. Neurosci. Res. 2008, 61, 143-158. [CrossRef] [PubMed]

175. Luuk, H.; Plaas, M.; Raud, S.; Innos, J.; Sütt, S.; Lasner, H.; Abramov, U.; Kurrikoff, K.; Kõks, S.; Vasar, E. WFS1-deficient mice display impaired behavioural adaptation in stressful environment. Behav. Brain Res. 2009, 198, 334-345. [CrossRef]

176. Sequeira, A.; Kim, C.; Seguin, M.; Lesage, A.; Chawky, N.; Desautels, A.; Tousignant, M.; Vanier, C.; Lipp, O.; Benkelfat, C.; et al. Wolfram syndrome and suicide: Evidence for a role of WFS1 in suicidal and impulsive behavior. Am. J. Med. Genet. Part B Neuropsychiatr. Genet. 2003, 119B, 108-113. [CrossRef]

177. Shrestha, P.; Mousa, A.; Heintz, N. Layer 2/3 pyramidal cells in the medial prefrontal cortex moderate stress induced depressive behaviors. eLife 2015, 4, e08752. [CrossRef]

178. Bonnet Wersinger, D.; Benkafadar, N.; Jagodzinska, J.; Hamel, C.; Tanizawa, Y.; Lenaers, G.; Delettre, C. Impairment of visual function and retinal ER stress activation in WFS1-deficient mice. PLoS ONE 2014, 9, e97222. [CrossRef] [PubMed]

179. El-Shanti, H.; Lidral, A.C.; Jarrah, N.; Druhan, L.; Ajlouni, K. Homozygosity Mapping Identifies an Additional Locus for Wolfram Syndrome on Chromosome 4q. Am. J. Hum. Genet. 2000, 66, 1229-1236. [CrossRef] [PubMed]

180. Wiley, S.E.; Andreyev, A.Y.; Divakaruni, A.S.; Karisch, R.; Perkins, G.; Wall, E.A.; van der Geer, P.; Chen, Y.-F.; Tsai, T.-F.; Simon, M.I.; et al. Wolfram Syndrome protein, Miner1, regulates sulphydryl redox status, the unfolded protein response, and Ca ${ }^{2+}$ homeostasis. EMBO Mol. Med. 2013, 5, 904-918. [CrossRef] [PubMed]

181. Rigoli, L.; Di Bella, C. Wolfram syndrome 1 and Wolfram syndrome 2. Curr. Opin. Pediatr. 2012, 24, 512-517. [CrossRef]

182. Al-Sheyyab, M.; Jarrah, N.; Younis, E.; Shennak, M.M.; Hadidi, A.; Awidi, A.; El-Shanti, H.; Ajlouni, K. Bleeding tendency in Wolfram syndrome: A newly identified feature with phenotype genotype correlation. Eur. J. Pediatr. 2001, 160, 243-246. [CrossRef]

183. Rigoli, L.; Bramanti, P.; Di Bella, C.; De Luca, F. Genetic and clinical aspects of Wolfram syndrome 1, a severe neurodegenerative disease. Pediatr. Res. 2018, 83, 921-929. [CrossRef]

184. Urano, F. Wolfram Syndrome: Diagnosis, Management, and Treatment. Curr. Diab. Rep. 2016, 16, 6. [CrossRef]

185. Crouzier, L.; Richard, E.M.; Diez, C.; Alzaeem, H.; Denus, M.; Cubedo, N.; Delaunay, T.; Glendenning, E.; Baxendale, S.; Whitfield, T.T.; et al. Morphological, behavioral and cellular analyses revealed different phenotype in 2 Wolfram syndrome WFS1a and WFS1b zebrafish mutant lines. Human Mol. Genet. 2021. Submitted.

186. Crouzier, L.; Richard, E.M.; Diez, C.; Alzaeem, H.; Denus, M.; Cubedo, N.; Maurice, T.; Delprat, B. NCS1 overexpression restored mitochondrial activity and behavioral anomalies in a novel zebrafish model of Wolfram syndrome. Molec. Ther. 2021. Submitted.

187. Kaufman, R.J.; Scheuner, D.; Schröder, M.; Shen, X.; Lee, K.; Liu, C.Y.; Arnold, S.M. The unfolded protein response in nutrient sensing and differentiation. Nat. Rev. Mol. Cell Biol. 2002, 3, 411-421. [CrossRef]

188. Mori, K. Tripartite management of unfolded proteins in the endoplasmic reticulum. Cell 2000, 101, 451-454. [CrossRef] 
189. Ariyasu, D.; Yoshida, H.; Hasegawa, Y. Endoplasmic Reticulum (ER) Stress and Endocrine Disorders. Int. J. Mol. Sci. 2017, 18, 382. [CrossRef] [PubMed]

190. Han, D.; Lerner, A.G.; Vande Walle, L.; Upton, J.-P.; Xu, W.; Hagen, A.; Backes, B.J.; Oakes, S.A.; Papa, F.R. IRE1alpha kinase activation modes control alternate endoribonuclease outputs to determine divergent cell fates. Cell 2009, 138, 562-575. [CrossRef] [PubMed]

191. Rutkowski, D.T.; Kaufman, R.J. That which does not kill me makes me stronger: Adapting to chronic ER stress. Trends Biochem. Sci. 2007, 32, 469-476. [CrossRef]

192. Bertolotti, A.; Zhang, Y.; Hendershot, L.M.; Harding, H.P.; Ron, D. Dynamic interaction of BiP and ER stress transducers in the unfolded-protein response. Nat. Cell Biol. 2000, 2, 326-332. [CrossRef]

193. Schröder, M.; Kaufman, R.J. ER stress and the unfolded protein response. Mutat. Res. 2005, 569, 29-63. [CrossRef]

194. Yoshida, H.; Okada, T.; Haze, K.; Yanagi, H.; Yura, T.; Negishi, M.; Mori, K. ATF6 Activated by Proteolysis Binds in the Presence of NF-Y (CBF) Directly to the cis-Acting Element Responsible for the Mammalian Unfolded Protein Response. Mol. Cell. Biol. 2000, 20, 6755-6767. [CrossRef]

195. Coelho, D.S.; Domingos, P.M. Physiological roles of regulated Ire1 dependent decay. Front. Genet. 2014, 5, 76. [CrossRef]

196. Martindale, J.J.; Fernandez, R.; Thuerauf, D.; Whittaker, R.; Gude, N.; Sussman, M.A.; Glembotski, C.C. Endoplasmic reticulum stress gene induction and protection from ischemia/reperfusion injury in the hearts of transgenic mice with a tamoxifen-regulated form of ATF6. Circ. Res. 2006, 98, 1186-1193. [CrossRef]

197. Schroder, M.; Kaufman, R.J. Divergent Roles of IRE1 $\alpha$ and PERK in the Unfolded Protein Response. Available online: https: //www.ingentaconnect.com/content/ben/cmm/2006/00000006/00000001/art00002 (accessed on 27 April 2020).

198. Lu, P.D.; Harding, H.P.; Ron, D. Translation reinitiation at alternative open reading frames regulates gene expression in an integrated stress response. J. Cell Biol. 2004, 167, 27-33. [CrossRef] [PubMed]

199. Harding, H.P.; Novoa, I.; Zhang, Y.; Zeng, H.; Wek, R.; Schapira, M.; Ron, D. Regulated Translation Initiation Controls StressInduced Gene Expression in Mammalian Cells. Mol. Cell 2000, 6, 1099-1108. [CrossRef]

200. Oyadomari, S.; Koizumi, A.; Takeda, K.; Gotoh, T.; Akira, S.; Araki, E.; Mori, M. Targeted disruption of the Chop gene delays endoplasmic reticulum stress-mediated diabetes. J. Clin. Investig. 2002, 109, 525-532. [CrossRef] [PubMed]

201. Zinszner, H.; Kuroda, M.; Wang, X.; Batchvarova, N.; Lightfoot, R.T.; Remotti, H.; Stevens, J.L.; Ron, D. CHOP is implicated in programmed cell death in response to impaired function of the endoplasmic reticulum. Genes Dev. 1998, 12, 982-995. [CrossRef]

202. Bruno, T.; De Nicola, F.; Iezzi, S.; Lecis, D.; D'Angelo, C.; Di Padova, M.; Corbi, N.; Dimiziani, L.; Zannini, L.; Jekimovs, C.; et al. Che-1 phosphorylation by ATM/ATR and Chk2 kinases activates p53 transcription and the G2/M checkpoint. Cancer Cell 2006, 10, 473-486. [CrossRef]

203. Bruno, T.; Iezzi, S.; De Nicola, F.; Di Padova, M.; Desantis, A.; Scarsella, M.; Di Certo, M.G.; Leonetti, C.; Floridi, A.; Passananti, C.; et al. Che-1 activates XIAP expression in response to DNA damage. Cell Death Differ. 2008, 15, 515-520. [CrossRef]

204. Ishigaki, S.; Fonseca, S.G.; Oslowski, C.M.; Jurczyk, A.; Shearstone, J.R.; Zhu, L.J.; Permutt, M.A.; Greiner, D.L.; Bortell, R.; Urano, F. AATF mediates anti-apoptotic effect of the unfolded protein response through transcriptional regulation of AKT1. Cell Death Differ. 2010, 17, 774-786. [CrossRef] [PubMed]

205. Ye, J.; Rawson, R.B.; Komuro, R.; Chen, X.; Davé, U.P.; Prywes, R.; Brown, M.S.; Goldstein, J.L. ER stress induces cleavage of membrane-bound ATF6 by the same proteases that process SREBPs. Mol. Cell 2000, 6, 1355-1364. [CrossRef]

206. Chen, X.; Karnovsky, A.; Sans, M.D.; Andrews, P.C.; Williams, J.A. Molecular characterization of the endoplasmic reticulum: Insights from proteomic studies. Proteomics 2010, 10, 4040-4052. [CrossRef]

207. Yamamoto, K.; Yoshida, H.; Kokame, K.; Kaufman, R.J.; Mori, K. Differential contributions of ATF6 and XBP1 to the activation of endoplasmic reticulum stress-responsive cis-acting elements ERSE, UPRE and ERSE-II. J. Biochem. 2004, 136, 343-350. [CrossRef] [PubMed]

208. Yoshida, H.; Matsui, T.; Yamamoto, A.; Okada, T.; Mori, K. XBP1 mRNA is induced by ATF6 and spliced by IRE1 in response to ER stress to produce a highly active transcription factor. Cell 2001, 107, 881-891. [CrossRef]

209. Fonseca, S.G.; Ishigaki, S.; Oslowski, C.M.; Lu, S.; Lipson, K.L.; Ghosh, R.; Hayashi, E.; Ishihara, H.; Oka, Y.; Permutt, M.A.; et al. Wolfram syndrome 1 gene negatively regulates ER stress signaling in rodent and human cells. J. Clin. Investig. 2010, 120, 744-755. [CrossRef] [PubMed]

210. Oslowski, C.M.; Urano, F. The binary switch that controls the life and death decisions of ER stressed beta cells. Curr. Opin. Cell Biol. 2011, 23, 207-215. [CrossRef]

211. Azim, M.; Surani, H. Glycoprotein synthesis and inhibition of glycosylation by tunicamycin in preimplantation mouse embryos: Compaction and trophoblast adhesion. Cell 1979, 18, 217-227. [CrossRef]

212. Hakulinen, J.K.; Hering, J.; Brändén, G.; Chen, H.; Snijder, A.; Ek, M.; Johansson, P. MraY-antibiotic complex reveals details of tunicamycin mode of action. Nat. Chem. Biol. 2017, 13, 265-267. [CrossRef]

213. Yoo, J.; Mashalidis, E.H.; Kuk, A.C.Y.; Yamamoto, K.; Kaeser, B.; Ichikawa, S.; Lee, S.-Y. GlcNAc-1-P-transferase-tunicamycin complex structure reveals basis for inhibition of N-glycosylation. Nat. Struct. Mol. Biol. 2018, 25, 217-224. [CrossRef]

214. Li, J.; Chen, Z.; Gao, L.-Y.; Colorni, A.; Ucko, M.; Fang, S.; Du, S.J. A transgenic zebrafish model for monitoring xbp1 splicing and endoplasmic reticulum stress in vivo. Mech. Dev. 2015, 137, 33-44. [CrossRef]

215. Clark, E.M.; Nonarath, H.J.T.; Bostrom, J.R.; Link, B.A. Establishment and validation of an endoplasmic reticulum stress reporter to monitor zebrafish ATF6 activity in development and disease. Dis. Models Mech. 2019, 13, dmm041426. [CrossRef] 
216. Lee, H.-C.; Chen, Y.-J.; Liu, Y.-W.; Lin, K.-Y.; Chen, S.-W.; Lin, C.-Y.; Lu, Y.-C.; Hsu, P.-C.; Lee, S.-C.; Tsai, H.-J. Transgenic zebrafish model to study translational control mediated by upstream open reading frame of human chop gene. Nucleic Acids Res. 2011, 39, e139. [CrossRef] [PubMed]

217. Joshi, A.U.; Kornfeld, O.S.; Mochly-Rosen, D. The Entangled ER-Mitochondrial axis as a potential therapeutic strategy in Neurodegeneration: A Tangled Duo Unchained. Cell Calcium 2016, 60, 218-234. [CrossRef]

218. Krols, M.; van Isterdael, G.; Asselbergh, B.; Kremer, A.; Lippens, S.; Timmerman, V.; Janssens, S. Mitochondria-associated membranes as hubs for neurodegeneration. Acta Neuropathol. 2016, 131, 505-523. [CrossRef] [PubMed]

219. Paillusson, S.; Stoica, R.; Gomez-Suaga, P.; Lau, D.H.W.; Mueller, S.; Miller, T.; Miller, C.C.J. There's Something Wrong with my MAM; the ER-Mitochondria Axis and Neurodegenerative Diseases. Trends Neurosci. 2016, 39, 146-157. [CrossRef]

220. Ruby, J.R.; Dyer, R.F.; Skalko, R.G. Continuities between mitochondria and endoplasmic reticulum in the mammalian ovary. Z. Zellforsch. Mikrosk. Anat. 1969, 97, 30-37. [CrossRef]

221. Delprat, B.; Maurice, T.; Delettre, C. Wolfram syndrome: MAMs' connection? Cell Death Dis. 2018, 9, 364. [CrossRef]

222. Colombini, M. The VDAC channel: Molecular basis for selectivity. Biochim. Biophys. Acta BBA Mol. Cell Res. 2016, 1863, $2498-2502$. [CrossRef] [PubMed]

223. Szabadkai, G.; Bianchi, K.; Várnai, P.; De Stefani, D.; Wieckowski, M.R.; Cavagna, D.; Nagy, A.I.; Balla, T.; Rizzuto, R. Chaperonemediated coupling of endoplasmic reticulum and mitochondrial $\mathrm{Ca}^{2+}$ channels. J. Cell Biol. 2006, 175, 901-911. [CrossRef]

224. Nakamura, T.Y.; Jeromin, A.; Mikoshiba, K.; Wakabayashi, S. Neuronal calcium sensor-1 promotes immature heart function and hypertrophy by enhancing $\mathrm{Ca}^{2+}$ signals. Circ. Res. 2011, 109, 512-523. [CrossRef] [PubMed]

225. Pongs, O.; Lindemeier, J.; Zhu, X.R.; Theil, T.; Engelkamp, D.; Krah-Jentgens, I.; Lambrecht, H.G.; Koch, K.W.; Schwemer, J.; Rivosecchi, R. Frequenin-A novel calcium-binding protein that modulates synaptic efficacy in the Drosophila nervous system. Neuron 1993, 11, 15-28. [CrossRef]

226. Saab, B.J.; Georgiou, J.; Nath, A.; Lee, F.J.S.; Wang, M.; Michalon, A.; Liu, F.; Mansuy, I.M.; Roder, J.C. NCS-1 in the dentate gyrus promotes exploration, synaptic plasticity, and rapid acquisition of spatial memory. Neuron 2009, 63, 643-656. [CrossRef]

227. Sippy, T.; Cruz-Martín, A.; Jeromin, A.; Schweizer, F.E. Acute changes in short-term plasticity at synapses with elevated levels of neuronal calcium sensor-1. Nat. Neurosci. 2003, 6, 1031-1038. [CrossRef] [PubMed]

228. Drumond, L.E.; Mourão, F.A.G.; Leite, H.R.; Abreu, R.V.; Reis, H.J.; Moraes, M.F.D.; Pereira, G.S.; Massensini, A.R. Differential effects of swimming training on neuronal calcium sensor-1 expression in rat hippocampus/cortex and in object recognition memory tasks. Brain Res. Bull. 2012, 88, 385-391. [CrossRef] [PubMed]

229. Hui, K.; Fei, G.-H.; Saab, B.J.; Su, J.; Roder, J.C.; Feng, Z.-P. Neuronal calcium sensor-1 modulation of optimal calcium level for neurite outgrowth. Dev. Camb. Engl. 2007, 134, 4479-4489. [CrossRef]

230. Nakamura, T.Y.; Jeromin, A.; Smith, G.; Kurushima, H.; Koga, H.; Nakabeppu, Y.; Wakabayashi, S.; Nabekura, J. Novel role of neuronal $\mathrm{Ca}^{2+}$ sensor-1 as a survival factor up-regulated in injured neurons. J. Cell Biol. 2006, 172, 1081-1091. [CrossRef] [PubMed]

231. Angebault, C.; Fauconnier, J.; Patergnani, S.; Rieusset, J.; Danese, A.; Affortit, C.A.; Jagodzinska, J.; Mégy, C.; Quiles, M.; Cazevieille, C.; et al. ER-mitochondria cross-talk is regulated by the $\mathrm{Ca}^{2+}$ sensor NCS1 and is impaired in Wolfram syndrome. Sci. Signal. 2018, 11, eaaq1380. [CrossRef] [PubMed]

232. Delprat, B.; Rieusset, J.; Delettre, C. Defective endoplasmic reticulum-mitochondria 2270 connection is a hallmark of Wolfram syndrome. Contact 2019, 2, 1-5. [CrossRef]

233. Ashworth, R. Approaches to measuring calcium in zebrafish: Focus on neuronal development. Cell Calcium 2004, 35, $393-402$. [CrossRef]

234. Ahrens, M.B.; Orger, M.B.; Robson, D.N.; Li, J.M.; Keller, P.J. Whole-brain functional imaging at cellular resolution using light-sheet microscopy. Nat. Methods 2013, 10, 413-420. [CrossRef]

235. Panier, T.; Romano, S.A.; Olive, R.; Pietri, T.; Sumbre, G.; Candelier, R.; Debrégeas, G. Fast functional imaging of multiple brain regions in intact zebrafish larvae using selective plane illumination microscopy. Front. Neural Circuits 2013, 7, 65. [CrossRef]

236. Yang, W.; Miller, J.K.; Carrillo-Reid, L.; Pnevmatikakis, E.; Paninski, L.; Yuste, R.; Peterka, D.S. Simultaneous Multi-plane Imaging of Neural Circuits. Neuron 2016, 89, 269-284. [CrossRef] [PubMed]

237. Mukamel, E.A.; Nimmerjahn, A.; Schnitzer, M.J. Automated Analysis of Cellular Signals from Large-Scale Calcium Imaging Data. Neuron 2009, 63, 747-760. [CrossRef]

238. Pnevmatikakis, E.A.; Soudry, D.; Gao, Y.; Machado, T.A.; Merel, J.; Pfau, D.; Reardon, T.; Mu, Y.; Lacefield, C.; Yang, W.; et al. Simultaneous Denoising, Deconvolution, and Demixing of Calcium Imaging Data. Neuron 2016, 89, 285-299. [CrossRef]

239. Chen, T.-W.; Wardill, T.J.; Sun, Y.; Pulver, S.R.; Renninger, S.L.; Baohan, A.; Schreiter, E.R.; Kerr, R.A.; Orger, M.B.; Jayaraman, V.; et al. Ultrasensitive fluorescent proteins for imaging neuronal activity. Nature 2013, 499, 295-300. [CrossRef]

240. Keller, P.J.; Ahrens, M.B. Visualizing Whole-Brain Activity and Development at the Single-Cell Level Using Light-Sheet Microscopy. Neuron 2015, 85, 462-483. [CrossRef]

241. Muto, A.; Ohkura, M.; Kotani, T.; Higashijima, S.-I.; Nakai, J.; Kawakami, K. Genetic visualization with an improved GCaMP calcium indicator reveals spatiotemporal activation of the spinal motor neurons in zebrafish. Proc. Natl. Acad. Sci. USA 2011, 108, 5425-5430. [CrossRef]

242. Liu, J.; Baraban, S.C. Network Properties Revealed during Multi-Scale Calcium Imaging of Seizure Activity in Zebrafish. eNeuro 2019, 6, ENEURO.0041-19.2019. [CrossRef] [PubMed] 
243. Muto, A.; Kawakami, K. Imaging functional neural circuits in zebrafish with a new GCaMP and the Gal4FF-UAS system. Commun. Integr. Biol. 2011, 4, 566-568. [CrossRef]

244. Esterberg, R.; Hailey, D.W.; Rubel, E.W.; Raible, D.W. ER-Mitochondrial Calcium Flow Underlies Vulnerability of Mechanosensory Hair Cells to Damage. J. Neurosci. 2014, 34, 9703-9719. [CrossRef] [PubMed]

245. Lagae, L. Dravet syndrome. Curr. Opin. Neurol. 2021, 34, 213-218. [CrossRef]

246. Rink, E.; Wullimann, M.F. The teleostean (zebrafish) dopaminergic system ascending to the subpallium (striatum) is located in the basal diencephalon (posterior tuberculum). Brain Res. 2001, 889, 316-330. [CrossRef]

247. Brunklaus, A.; Zuberi, S.M. Dravet syndrome-From epileptic encephalopathy to channelopathy. Epilepsia 2014, 55, 979-984. [CrossRef] [PubMed]

248. Bayat, A.; Hjalgrim, H.; Møller, R.S. The incidence of SCN1A-related Dravet syndrome in Denmark is 1:22,000: A population-based study from 2004 to 2009. Epilepsia 2015, 56, e36-e39. [CrossRef] [PubMed]

249. Connolly, M.B. Dravet Syndrome: Diagnosis and Long-Term Course. Can. J. Neurol. Sci. 2016, 43, S3-S8. [CrossRef]

250. Darra, F.; Battaglia, D.; Dravet, C.; Patrini, M.; Offredi, F.; Chieffo, D.; Piazza, E.; Fontana, E.; Olivieri, G.; Turrini, I.; et al. Dravet syndrome: Early electroclinical findings and long-term outcome in adolescents and adults. Epilepsia 2019, 60, S49-S58. [CrossRef]

251. Li, W.; Schneider, A.L.; Scheffer, I.E. Defining Dravet syndrome: An essential pre-requisite for precision medicine trials. Epilepsia 2021, 62, 2205-2217. [CrossRef]

252. Shmuely, S.; Sisodiya, S.M.; Gunning, W.B.; Sander, J.W.; Thijs, R.D. Mortality in Dravet syndrome: A review. Epilepsy Behav. 2016, 64, 69-74. [CrossRef]

253. Al-Baradie, R.S. Dravet syndrome, what is new? Neurosciences 2013, 18, 11-17.

254. Scheffer, I.E.; Nabbout, R. SCN1A-related phenotypes: Epilepsy and beyond. Epilepsia 2019, 60, S17-S24. [CrossRef]

255. Guerrini, R.; Striano, P.; Catarino, C.; Sisodiya, S.M. Neuroimaging and neuropathology of Dravet syndrome: Neuroimaging and Neuropathology of Dravet Syndrome. Epilepsia 2011, 52, 30-34. [CrossRef] [PubMed]

256. Lee, Y.-J.; Yum, M.-S.; Kim, M.-J.; Shim, W.-H.; Yoon, H.M.; Yoo, I.H.; Lee, J.; Lim, B.C.; Kim, K.J.; Ko, T.-S. Large-scale structural alteration of brain in epileptic children with SCN1A mutation. NeuroImage Clin. 2017, 15, 594-600. [CrossRef]

257. Schoonheim, P.J.; Arrenberg, A.B.; Del Bene, F.; Baier, H. Optogenetic Localization and Genetic Perturbation of Saccade-Generating Neurons in Zebrafish. J. Neurosci. 2010, 30, 7111-7120. [CrossRef]

258. Dinday, M.T.; Baraban, S.C. Large-Scale Phenotype-Based Antiepileptic Drug Screening in a Zebrafish Model of Dravet Syndrome. eNeuro 2015, 2, ENEURO.0068-15.2015. [CrossRef] [PubMed]

259. Eimon, P.M.; Ghannad-Rezaie, M.; De Rienzo, G.; Allalou, A.; Wu, Y.; Gao, M.; Roy, A.; Skolnick, J.; Yanik, M.F. Brain activity patterns in high-throughput electrophysiology screen predict both drug efficacies and side effects. Nat. Commun. 2018, 9, 219. [CrossRef] [PubMed]

260. Ademuwagun, I.A.; Rotimi, S.O.; Syrbe, S.; Ajamma, Y.U.; Adebiyi, E. Voltage Gated Sodium Channel Genes in Epilepsy: Mutations, Functional Studies, and Treatment Dimensions. Front. Neurol. 2021, 12, 600050. [CrossRef] [PubMed]

261. Novak, A.E.; Taylor, A.D.; Pineda, R.H.; Lasda, E.L.; Wright, M.A.; Ribera, A.B. Embryonic and larval expression of zebrafish voltage-gated sodium channel $\alpha$-subunit genes. Dev. Dyn. 2006, 235, 1962-1973. [CrossRef]

262. Zhang, Y.; Kecskés, A.; Copmans, D.; Langlois, M.; Crawford, A.D.; Ceulemans, B.; Lagae, L.; de Witte, P.A.M.; Esguerra, C.V. Pharmacological Characterization of an Antisense Knockdown Zebrafish Model of Dravet Syndrome: Inhibition of Epileptic Seizures by the Serotonin Agonist Fenfluramine. PLoS ONE 2015, 10, e0125898. [CrossRef]

263. Schoonjans, A.-S.; Lagae, L.; Ceulemans, B. Low-dose fenfluramine in the treatment of neurologic disorders: Experience in Dravet syndrome. Ther. Adv. Neurol. Disord. 2015, 8, 328-338. [CrossRef]

264. Brenet, A.; Hassan-Abdi, R.; Somkhit, J.; Yanicostas, C.; Soussi-Yanicostas, N. Defective Excitatory/Inhibitory Synaptic Balance and Increased Neuron Apoptosis in a Zebrafish Model of Dravet Syndrome. Cells 2019, 8, 1199. [CrossRef]

265. Grone, B.P.; Qu, T.; Baraban, S.C. Behavioral Comorbidities and Drug Treatments in a Zebrafish scn1lab Model of Dravet Syndrome. eNeuro 2017, 4, ENEURO.0066-17.2017. [CrossRef]

266. Stahl, S.M. Mechanism of Action of Trazodone: A Multifunctional Drug. CNS Spectr. 2009, 14, 536-546. [CrossRef]

267. Cacabelos, R. Parkinson's Disease: From Pathogenesis to Pharmacogenomics. Int. J. Mol. Sci. 2017, 18, 551. [CrossRef] [PubMed]

268. Griffin, A.; Hamling, K.R.; Hong, S.; Anvar, M.; Lee, L.P.; Baraban, S.C. Preclinical Animal Models for Dravet Syndrome: Seizure Phenotypes, Comorbidities and Drug Screening. Front. Pharmacol. 2018, 9, 573. [CrossRef]

269. Banerji, R.; Huynh, C.; Figueroa, F.; Dinday, M.T.; Baraban, S.C.; Patel, M. Enhancing glucose metabolism via gluconeogenesis is therapeutic in a zebrafish model of Dravet syndrome. Brain Commun. 2021, 3, fcab004. [CrossRef] [PubMed]

270. Kumar, M.G.; Rowley, S.; Fulton, R.; Dinday, M.T.; Baraban, S.C.; Patel, M. Altered Glycolysis and Mitochondrial Respiration in a Zebrafish Model of Dravet Syndrome. eNeuro 2016, 3, ENEURO.0008-16.2016. [CrossRef]

271. Weuring, W.J.; Singh, S.; Volkers, L.; Rook, M.B.; van't Slot, R.H.; Bosma, M.; Inserra, M.; Vetter, I.; Verhoeven-Duif, N.M.; Braun, K.P.J.; et al. NaV1.1 and NaV1.6 selective compounds reduce the behavior phenotype and epileptiform activity in a novel zebrafish model for Dravet Syndrome. PLoS ONE 2020, 15, e0219106. [CrossRef] [PubMed]

272. Nabbout, R.; Mistry, A.; Zuberi, S.; Villeneuve, N.; Gil-Nagel, A.; Sanchez-Carpintero, R.; Stephani, U.; Laux, L.; Wirrell, E.; Knupp, K.; et al. Fenfluramine for Treatment-Resistant Seizures in Patients with Dravet Syndrome Receiving Stiripentol-Inclusive Regimens: A Randomized Clinical Trial. JAMA Neurol. 2020, 77, 300. [CrossRef] 
273. Lagae, L.; Schoonjans, A.-S.; Gammaitoni, A.R.; Galer, B.S.; Ceulemans, B. A pilot, open-label study of the effectiveness and tolerability of low-dose ZX008 (fenfluramine $\mathrm{HCl}$ ) in Lennox-Gastaut syndrome. Epilepsia 2018, 59, 1881-1888. [CrossRef]

274. Geenen, K.R.; Doshi, S.P.; Patel, S.; Sourbron, J.; Falk, A.; Morgan, A.; Vu, U.; Bruno, P.L.; Thiele, E.A. Fenfluramine for seizures associated with Sunflower syndrome. Dev. Med. Child Neurol. 2021, 63, 1427-1432. [CrossRef]

275. Poyurovsky, M.; Weizman, A. Treatment of Antipsychotic-Induced Akathisia: Role of Serotonin 5-HT2a Receptor Antagonists. Drugs 2020, 80, 871-882. [CrossRef]

276. Jarema, M.; Dudek, D.; Landowski, J.; Heitzman, J.; Rabe-Jabłońska, J.; Rybakowski, J. Trazodon—The antidepressant: Mechanism of action and its position in the treatment of depression. Psychiatr. Pol. 2011, 45, 611-625.

277. Karaki, S.; Becamel, C.; Murat, S.; la Cour, C.M.; Millan, M.J.; Prézeau, L.; Bockaert, J.; Marin, P.; Vandermoere, F. Quantitative phosphoproteomics unravels biased phosphorylation of serotonin 2A receptor at Ser280 by hallucinogenic versus nonhallucinogenic agonists. Mol. Cell. Proteom. MCP 2014, 13, 1273-1285. [CrossRef] [PubMed]

278. Del Bene, E.; Poggioni, M.; Michelacci, S. Lisuride as a migraine prophylactic in children: An open clinical trial. Int. J. Clin. Pharmacol. Res. 1983, 3, 137-141.

279. Obeso, J.A.; Rothwell, J.C.; Quinn, N.P.; Lang, A.E.; Thompson, C.; Marsden, C.D. Cortical Reflex Myoclonus Responds to Intravenous Lisuride. Clin. Neuropharmacol. 1983, 6, 231-240. [CrossRef]

280. Hofmann, C.; Penner, U.; Dorow, R.; Pertz, H.H.; Jähnichen, S.; Horowski, R.; Latté, K.P.; Palla, D.; Schurad, B. Lisuride, a dopamine receptor agonist with 5-HT2B receptor antagonist properties: Absence of cardiac valvulopathy adverse drug reaction reports supports the concept of a crucial role for 5-HT2B receptor agonism in cardiac valvular fibrosis. Clin. Neuropharmacol. 2006, 29, 80-86. [CrossRef]

281. Catterall, W.A. Dravet syndrome: A sodium channel interneuronopathy. Curr. Opin. Physiol. 2018, 2, 42-50. [CrossRef] [PubMed]

282. Tai, C.; Abe, Y.; Westenbroek, R.E.; Scheuer, T.; Catterall, W.A. Impaired excitability of somatostatin- and parvalbumin-expressing cortical interneurons in a mouse model of Dravet syndrome. Proc. Natl. Acad. Sci. USA 2014, 111, E3139-E3148. [CrossRef] [PubMed]

283. Shen, R.-Y.; Andrade, R. 5-Hydroxytryptamine2 Receptor Facilitates GABAergic Neurotransmission in Rat Hippocampus. J. Pharmacol. Exp. Ther. 1998, 285, 805-812. [PubMed]

284. Guiard, B.P.; Giovanni, G.D. Central serotonin-2A (5-HT2A) receptor dysfunction in depression and epilepsy: The missing link? Front. Pharmacol. 2015, 6, 46. [CrossRef] [PubMed]

285. Svob Strac, D.; Pivac, N.; Smolders, I.J.; Fogel, W.A.; De Deurwaerdere, P.; Di Giovanni, G. Monoaminergic Mechanisms in Epilepsy May Offer Innovative Therapeutic Opportunity for Monoaminergic Multi-Target Drugs. Front. Neurosci. 2016, 10, 492. [CrossRef]

286. Deidda, G.; Crunelli, V.; Di Giovanni, G. 5-HT/GABA interaction in epilepsy. Prog. Brain Res. 2021, 259, 265-286. [CrossRef]

287. Buchanan, G.F.; Murray, N.M.; Hajek, M.A.; Richerson, G.B. Serotonin neurones have anti-convulsant effects and reduce seizure-induced mortality. J. Physiol. 2014, 592, 4395-4410. [CrossRef] [PubMed]

288. Buchanan, G.F.; Smith, H.R.; MacAskill, A.; Richerson, G.B. 5-HT $2 \mathrm{~A}$ receptor activation is necessary for $\mathrm{CO}_{2}$-induced arousal. J. Neurophysiol. 2015, 114, 233-243. [CrossRef] [PubMed]

289. Petrucci, A.N.; Joyal, K.G.; Purnell, B.S.; Buchanan, G.F. Serotonin and sudden unexpected death in epilepsy. Exp. Neurol. 2020, 325, 113145. [CrossRef]

290. De Witte, P.; Lagae, L. Serotonergic modulation as a pharmacological modality in the treatment of Dravet syndrome. Brain 2017, 140, e35. [CrossRef]

291. Brennan, T.J.; Seeley, W.W.; Kilgard, M.; Schreiner, C.E.; Tecott, L.H. Sound-Induced Seizures in Serotonin 5-HT2c Receptor Mutant Mice. Nat. Genet. 1997, 16, 387-390. [CrossRef]

292. Di Giovanni, G.; De Deurwaerdère, P. New therapeutic opportunities for 5-HT2C receptor ligands in neuropsychiatric disorders. Pharmacol. Ther. 2016, 157, 125-162. [CrossRef] [PubMed]

293. Isaac, M. Serotonergic 5-HT2C Receptors as a Potential Therapeutic Target for the Design Antiepileptic Drugs. Curr. Top. Med. Chem. 2005, 5, 59-67. [CrossRef]

294. Silenieks, L.B.; Carroll, N.K.; Van Niekerk, A.; Van Niekerk, E.; Taylor, C.; Upton, N.; Higgins, G.A. Evaluation of Selective 5-HT2C Agonists in Acute Seizure Models. ACS Chem. Neurosci. 2019, 10, 3284-3295. [CrossRef]

295. Panczyk, K.; Golda, S.; Waszkielewicz, A.; Zelaszczyk, D.; Gunia-Krzyzak, A.; Marona, H. Serotonergic system and its role in epilepsy and neuropathic pain treatment: A review based on receptor ligands. Curr. Pharm. Des. 2015, 21, 1723-1740. [CrossRef]

296. Cheng, J.; Kozikowski, A.P. We Need 2C but Not 2B: Developing Serotonin 2C (5-HT 2 C) Receptor Agonists for the Treatment of CNS Disorders. ChemMedChem 2015, 10, 1963-1967. [CrossRef]

297. Elangbam, C.S. Drug-induced Valvulopathy: An Update. Toxicol. Pathol. 2010, 38, 837-848. [CrossRef]

298. Rothman, R.B.; Baumann, M.H. Serotonergic drugs and valvular heart disease. Expert Opin. Drug Saf. 2009, 8, 317-329. [CrossRef]

299. Rothman, R.B.; Baumann, M.H.; Savage, J.E.; Rauser, L.; McBride, A.; Hufeisen, S.J.; Roth, B.L. Evidence for possible involvement of $5-\mathrm{HT}_{2 \mathrm{~B}}$ receptors in the cardiac valvulopathy associated with fenfluramine and other serotonergic medications. Circulation 2000, 102, 2836-2841. [CrossRef]

300. Schoonjans, A.; Ceulemans, B. An Old Drug for a New Indication: Repurposing Fenfluramine from an Anorexigen to an Antiepileptic Drug. Clin. Pharmacol. Ther. 2019, 106, 929-932. [CrossRef] 
301. Li, R.; Serdula, M.K.; Williamson, D.F.; Bowman, B.A.; Graham, D.J.; Green, L. Dose-effect of fenfluramine use on the severity of valvular heart disease among fen-phen patients with valvulopathy. Int. J. Obes. 1999, 23, 926-928. [CrossRef] [PubMed]

302. Schoonjans, A.-S.; Ceulemans, B. A critical evaluation of fenfluramine hydrochloride for the treatment of Dravet syndrome. Expert Rev. Neurother. 2021, 1-14, in press. [CrossRef]

303. Hatini, P.G.; Commons, K.G. A 5-HT 1 D -receptor agonist protects Dravet syndrome mice from seizure and early death. Eur. J. Neurosci. 2020, 52, 4370-4374. [CrossRef] [PubMed]

304. Rodríguez-Muñoz, M.; Sánchez-Blázquez, P.; Garzón, J. Fenfluramine diminishes NMDA receptor-mediated seizures via its mixed activity at serotonin 5HT2A and type 1 sigma receptors. Oncotarget 2018, 9, 23373-23389. [CrossRef]

305. Tupal, S.; Faingold, C.L. Fenfluramine, a serotonin-releasing drug, prevents seizure-induced respiratory arrest and is anticonvulsant in the DBA/1 mouse model of SUDEP. Epilepsia 2019, 60, 485-494. [CrossRef] [PubMed]

306. Tupal, S.; Faingold, C.L. Serotonin 5-HT4 receptors play a critical role in the action of fenfluramine to block seizure-induced sudden death in a mouse model of SUDEP. Epilepsy Res. 2021, 177, 106777. [CrossRef]

307. Gogou, M.; Cross, J.H. Fenfluramine as antiseizure medication for epilepsy. Dev. Med. Child Neurol. 2021, 63, 899-907. [CrossRef] [PubMed]

308. Martin, P.; de Witte, P.A.M.; Maurice, T.; Gammaitoni, A.; Farfel, G.; Galer, B. Fenfluramine acts as a positive modulator of sigma-1 receptors. Epilepsy Behav. 2020, 105, 106989. [CrossRef] [PubMed]

309. Martin, P.; Reeder, T.; Sourbron, J.; de Witte, P.A.M.; Gammaitoni, A.R.; Galer, B.S. An Emerging Role for Sigma-1 Receptors in the Treatment of Developmental and Epileptic Encephalopathies. Int. J. Mol. Sci. 2021, 22, 8416. [CrossRef] [PubMed]

310. Koboldt, D.C.; Steinberg, K.M.; Larson, D.E.; Wilson, R.K.; Mardis, E.R. The next-generation sequencing revolution and its impact on genomics. Cell 2013, 155, 27-38. [CrossRef]

311. Woerner, A.C.; Gallagher, R.C.; Vockley, J.; Adhikari, A.N. The Use of Whole Genome and Exome Sequencing for Newborn Screening: Challenges and Opportunities for Population Health. Front. Pediatr. 2021, 9, 663752. [CrossRef]

312. Pickett, S.B.; Raible, D.W. Water Waves to Sound Waves: Using Zebrafish to Explore Hair Cell Biology. J. Assoc. Res. Otolaryngol. JARO 2019, 20, 1-19. [CrossRef]

313. Van Wijk, R.C.; Krekels, E.H.J.; Kantae, V.; Ordas, A.; Kreling, T.; Harms, A.C.; Hankemeier, T.; Spaink, H.P.; van der Graaf, P.H. Mechanistic and Quantitative Understanding of Pharmacokinetics in Zebrafish Larvae through Nanoscale Blood Sampling and Metabolite Modeling of Paracetamol. J. Pharmacol. Exp. Ther. 2019, 371, 15-24. [CrossRef]

314. Guarin, M.; Ny, A.; De Croze, N.; Maes, J.; Léonard, M.; Annaert, P.; de Witte, P.A.M. Pharmacokinetics in Zebrafish Embryos (ZFE) following Immersion and Intrayolk Administration: A Fluorescence-Based Analysis. Pharmaceuticals 2021, 14, 576. [CrossRef] [PubMed] 